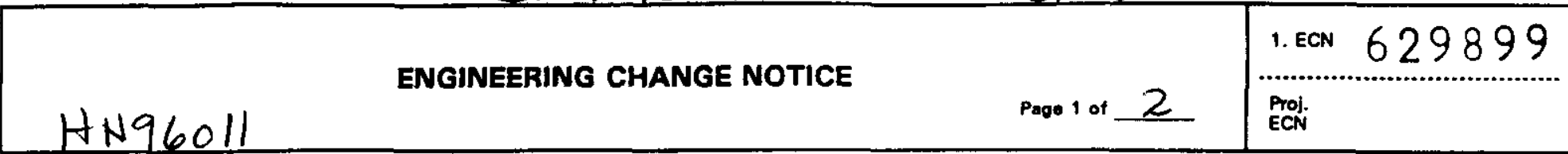

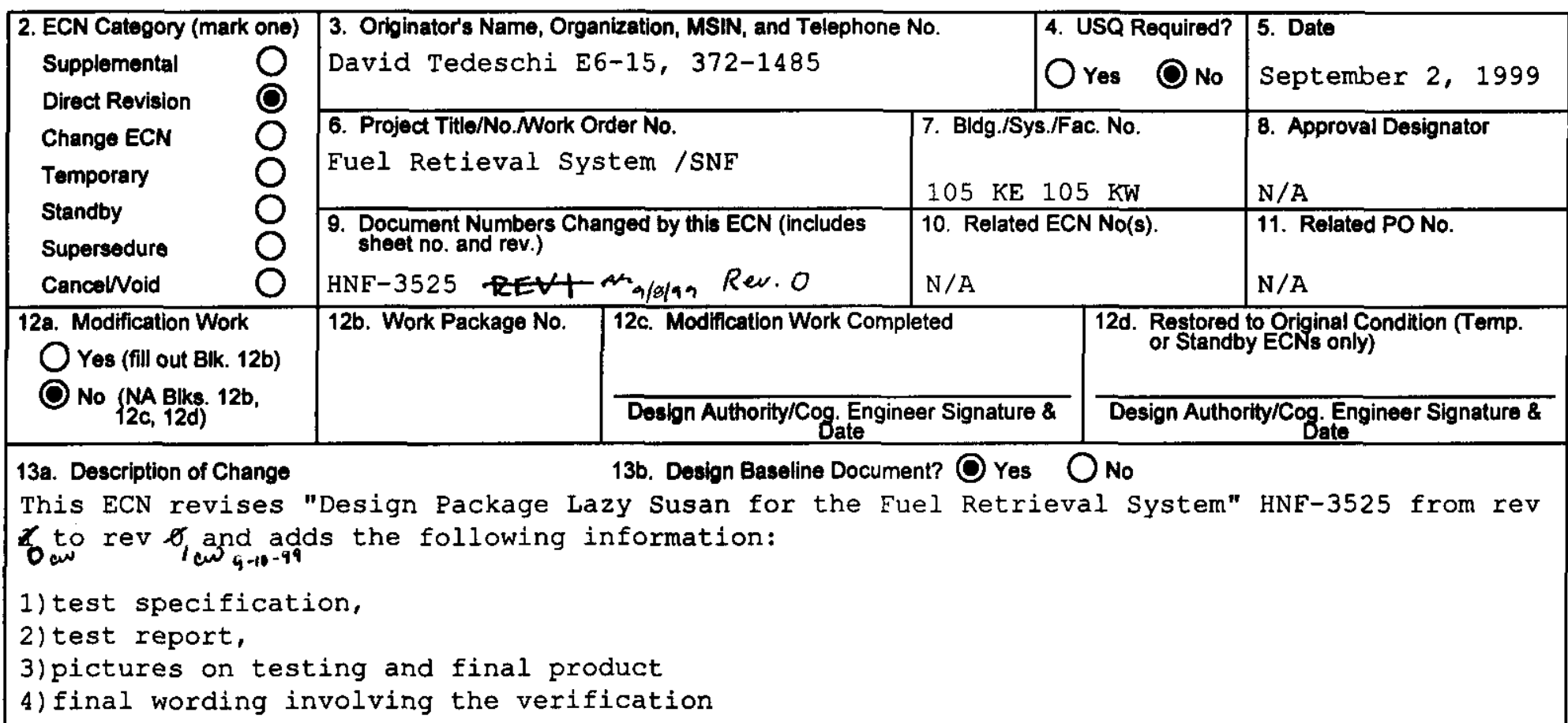

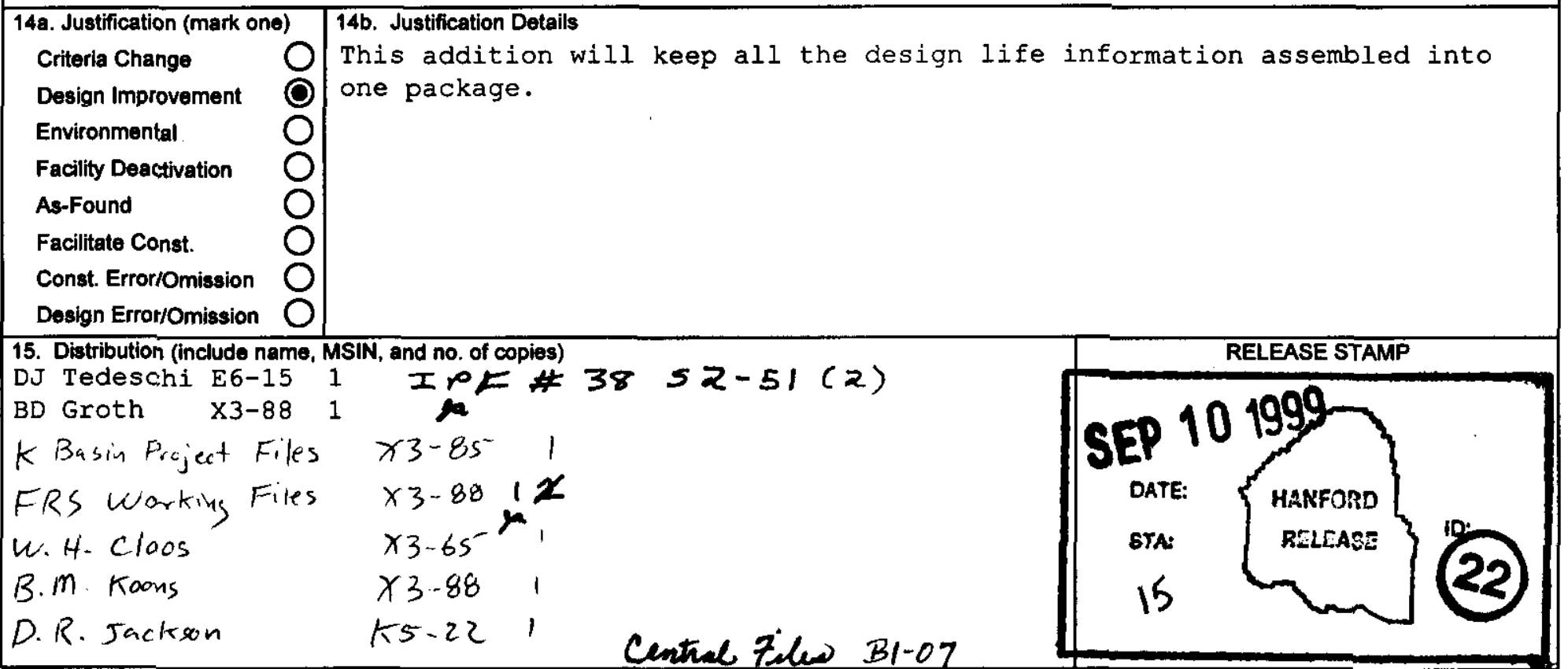


ENGINEERING CHANGE NOTICE

Page 2 of 2

17. Cost Impact

16. Design Verification Required

OYes

O No
ENGINEERING

Additional $O \$ N / A$

Savings $O \$ N / A$
CONSTRUCTION

Additional $\bigcirc \$ N / A$

Savings s

$\$ N / A$
1. ECN (use no. from pg. 1)

629899

18. Schedule impact (days)

Improvement

$\mathrm{N} / \mathrm{A}$

Delay

19. Change Impact Review: Indicate the related documents (other than the engineering documents identified on Side 1) that will be affected by the change described in Block 13. Enter the affected document number in Block 20 .

\section{SDD/DD}

Functional Design Criteria

Operating Specification

Criticality Specification

Conceptual Design Report

Equipment Spec.

Const. Spec.

Procurement Spec.

Vendor Information

OM Manual

FSARISAR

Safety Equipment List

Radiation Work Permit

Environmental Impact Statement

Environmental Report

Environmental Permit $\square$
$\square$
$\square$
$\square$
$\square$
$\square$
$\square$
$\square$
$\square$
$\square$
$\square$
$\square$
$\square$
$\square$
$\square$

Seismid/Stress Analysis
Stress/Dosign Report
Interface Control Drawing
Calibration Procedure
Installation Procedure
Maintenance Procedure
Engineering Procedure
Operating Instruction
Operating Procedure
Operational Safety Requirement
IEFD Drawing
Cell Arrangement Drawing
Essential Material Specification
Fac. Proc. Samp. Schedule
Inspection Plan
Inventory Adjustment Request

Tank Calibration Manual Health Physics Procedure

Spares Multiple Unit Listing

Test Procodures/Specification

Component Index

ASME Coded Item

Human Factor Consideration

Computer Software

Electric Circuit Schedule

ICRS Procedure

Process Control Manual/Plan

Process Flow Chart

Purchase Requisition

Tickler File

None

0. Other Affected Documents: (NOTE: Documents listed below will not be revised by this ECN.) Signatures below indicate that the signing organization has been notified of other affected documents listed below.

Document Number/Revision

Document Number/Revision

Document Number/Revision

None

\section{Approvals}

Signature

Design Authority BQtecth

Cog. Eng.

Cog. Mgr

QA

Safety

Environ.

Other

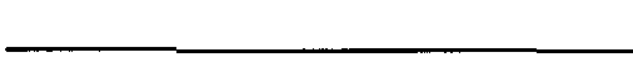

Date

$9 / 9 / 99$
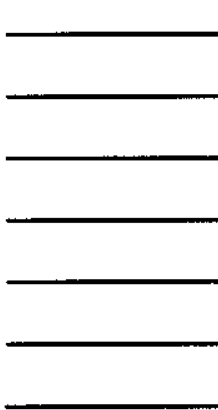

Design Agent ID Zadede

PE

QA

Safety

Design

Environ

Other

\section{DEPARTMENT OF ENERGY}

Signature or a Control Number that tracks the Approval Signature

\section{ADDITIONAL}

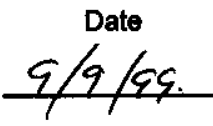

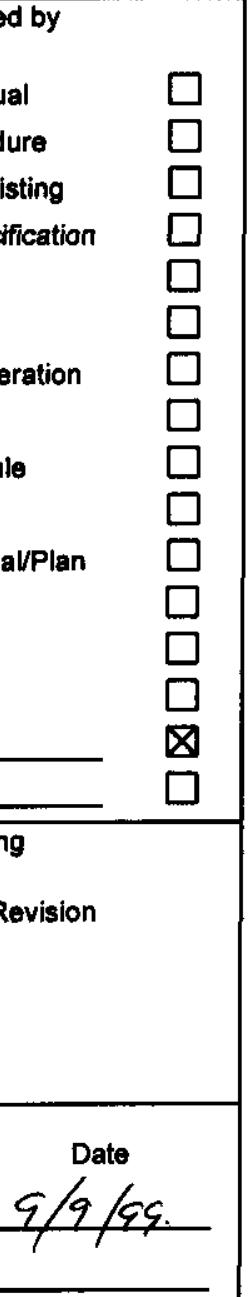




\title{
Design Package Lazy Susan For The Fuel Retrieval System
}

\author{
David Tedeschi \\ for Duke Engineering and Services Hanford, Richland, WA 99352 \\ U.S. Department of Energy Contract DE-AC06-96RL13200
}

EDT/ECN: 629899

Org Code: 21371

B\&R Code: EW 7040000
UC: 2050

Charge Code: CACN: 105491 COA: DM00 RN 960311 Total Pages: 46

Key Words: Spent Nuclear Fuel, Stinger, Fuel Handling Tool, Fuel Retrieval System, Lazy Susan

Abstract: This is a design package that contains the details for a Lazy Susan style small tool for the Fuel Retrieval System. The Lazy Susan tool is used to help rotate an MCO Fuel Basket when loading it. This document contains requirements, development design information, tests and test reports that pertain to the production of Lazy Susan small tool.

TRADEMARK DISCLAIMER. Reference herein to any specific commercial product, process, or service by trade name, trademark, manufacturer, or otherwise, does not necessarily constitute or imply its endorsement, recommendation, or favoring by the United States Government or any agency thereof or its contractors or subcontractors.

Printed in the United States of America. To obtein coples of this document, contact: Document Control Services, P.O. Box 950, Mailstop H6-08, Richland WA 99352, Phone (509) 372-2420; Fax (509) 376-4989.

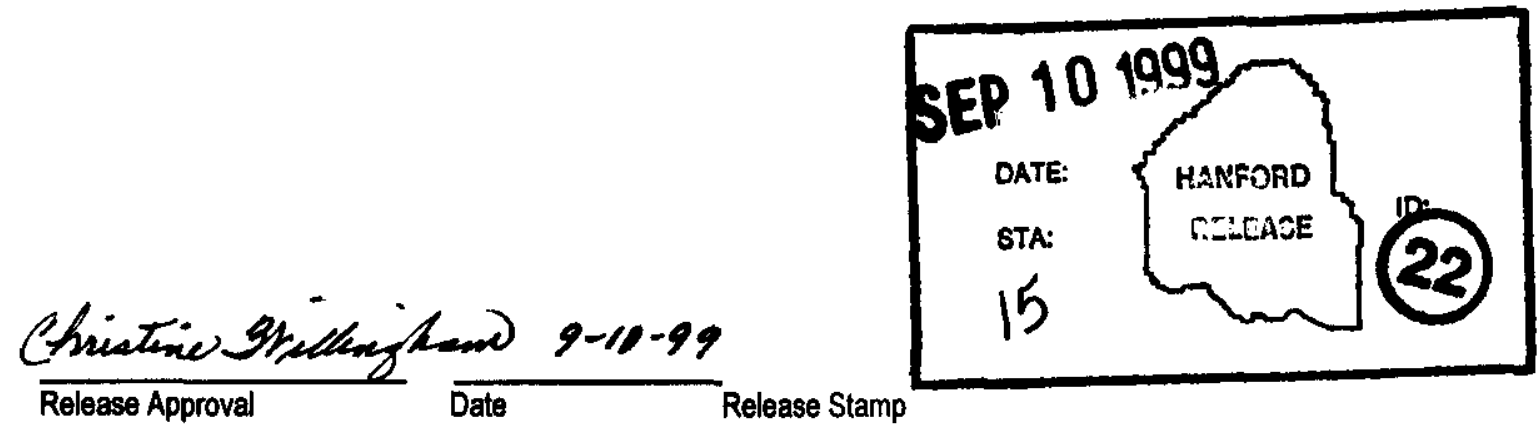

\section{Approved for Public Release}




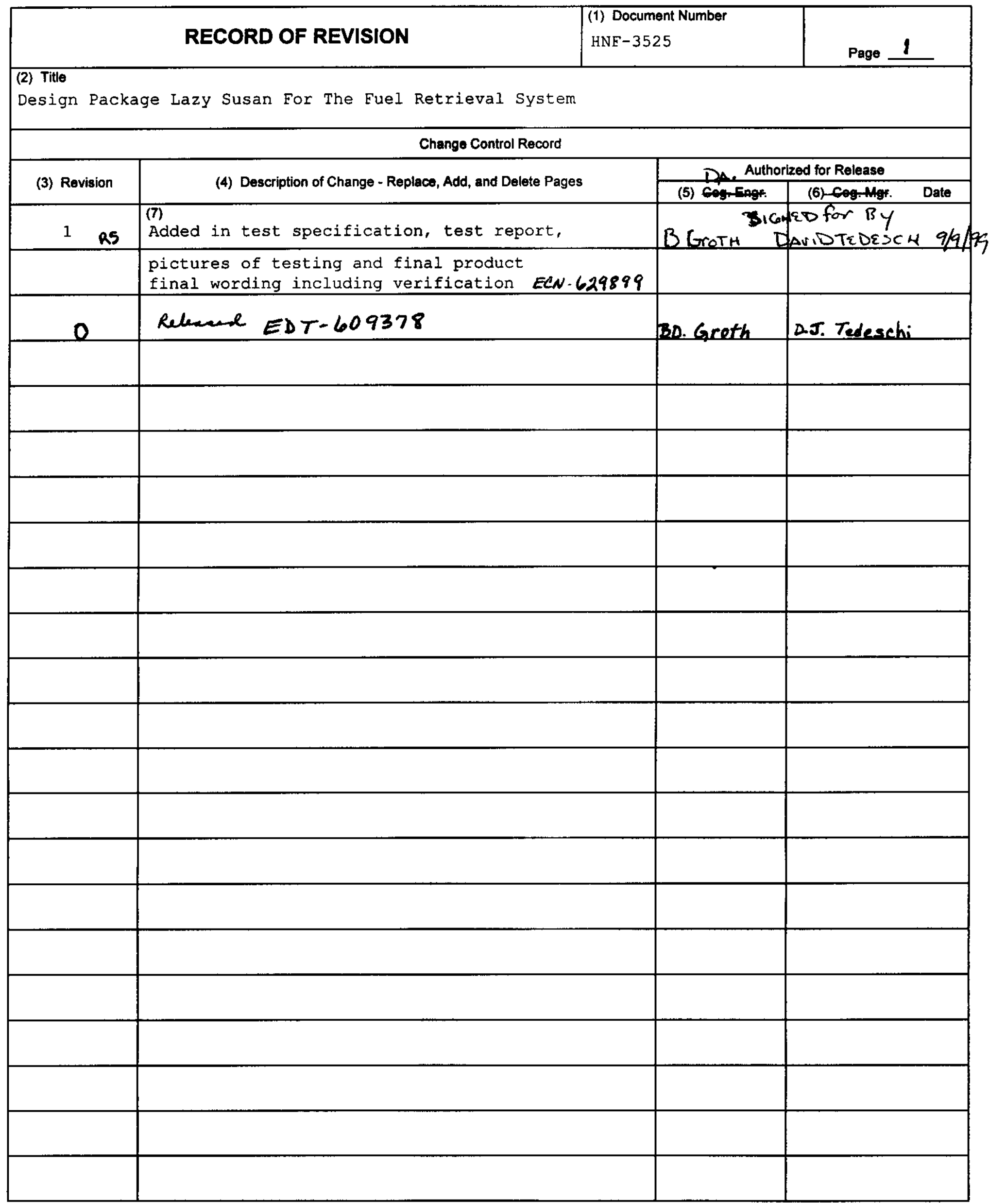




\section{Design Package}

\section{Lazy Susan for the Fuel Retrieval System \\ HNF-3525 Rev. 1}

September 9, 1999

By David Tedeschi

Of

Flour Daniel Northwest

1200 Jadwin

Richland, WA 99352

For Bruce Groth

of

Spent Nuclear Fuels Project

page 1 


\subsection{Introduction}

The Fuel Retrieval System (FRS) Subproject at Hanford's $100 \mathrm{~K}$ basins Spent Nuclear Fuel Project has employed robotic arms (named Konan) to load fuel elements into long term storage baskets.

This robotic arm has been tested and continues to be used for training. The testing and training has shown that a method is required to help turn the MCO fuel basket while loading. Use of a manual style "Lazy Susan" platform worked well in testing but needed refined to meet the conditions of operation. This design package documents the development of a "Lazy Susan" style device that will be capable of meeting all the design requirements FRS requires for operation.

\subsection{Scope}

\subsection{Objectives}

The scope of this design package is to document the design, fabrication, and testing of a "Lazy Susan" style platform for holding the fuel baskets during FRS loading operations.

\subsection{Products Delivered}

This package will deliver the following:

Documents

1) This document, which includes product requirements, analysis, graphical depictions, tests and reports.

2) Hanford formatted drawings

3) Vendor information

4) Procurement documentation

Hardware

1) Four "Lazy Susan" style platforms

\subsection{Products Requirements and Constraints}

The general design requirements/criteria for the Spent Nuclear Fuel Project Fuel Retrieval subproject is in HNF-S-0461, Specification For Design OfThe SNF Project Fuel Retrieval Subproject. The following requirements are additional or clarify it for the Lazy Susan. 


\section{Fuel Retrieval System Small Tools Design Package}

Lazy Susan

HNF-3525 Rev. 1

September 9, 1999

Page 3

\subsection{Dimensional/Physical Constraints}

a) Platform must fit within the fuel basket loading station (24 inches in diameter) as defined by Westinghouse supplied drawing DAG-327.

b) Platform must keep the height of the fuel basket to no greater than 3 to 4 inches above the process table for Mark I A (23.125 inches tall) and Mark IV (27.8 inches tall) MCO Fuel Baskets. MCO Fuel Baskets dimensions taken from drawing H-2-828060.

c) Platform needs to be round with a diameter of no greater than 22 inches (consistent with the Mark IV) and no less than 14 inches.

d) Platform shall not interfere with light tube as described by Westinghouse supplied drawing DAG-327.

\subsection{Environmental Constraints}

a) Platform material must be able to withstand the effects of high radiation field of $40 \mathrm{rem} / \mathrm{hr}$. This value is a conservative interpretation of BNFL Inc. Report L/B-SD-SNF-RPT-04, Radiological Shielding Design Plan for the SNF Fuel Retrieval Project.

b) Platform must be able to be submersed in deionized water at a temperature of $50^{\circ} \mathrm{F}$ for a period of its design life.

c) Platform must be able to handle a semi-abrasive environment, suspended metal particulates without deterioration for the period of its design life.

d) No grease or petroleum based material lubricant can be used.

\subsection{Operational Requirements}

a) Platform shall have a 3 year operating life, assuming the bearing is rotated $1 / 4$ turn every 15 minutes during those 3 years.

b) Platform shall be capable of rotating $360^{\circ}$ using the Konan robotic arm with a fully loaded Mark IV fuel basket on it.

c) Platform will operate under 16-20 feet of water. 


\section{Fuel Retrieval System Small Tools Design Package}

Lazy Susan

HNF-3525 Rev. 1

September 9, 1999

Page 4

d) Platform shall not restrict light from shining up through the bottom of a MCO Fuel Basket.

e) Platform shall be capable of supporting a fully loaded Mark IV fuel basket $(3500 \mathrm{lbs}$.) but be designed for $5000 \mathrm{lbs}$.

f) Platform shall be capable of withstanding an impact load from a fuel element dropping 36 inches with the basket nearly loaded.

\subsection{Maintenance Requirements}

a) Platform shall be remotely replaceable with manipulators and/or long pole tools and overhead cranes.

b) Platform will be replaced rather than repaired if a premature failure were to occur.

\subsection{Applicable Laws, Regulations, and Standards}

Applicable Fluor Daniel Hanford Engineering procedures shall be used for documenting development stages of design, reviews, and approvals of engineering documents.

\subsection{Development of Product}

\subsection{Management of Task}

\subsubsection{Engineering}

Engineering will be done using Fluor Daniel Northwest.

Documents will be reviewed and approved by Duke Engineering \& Services Hanford.

\subsubsection{Procurement}

Developmental materials will be procured using credit cards from Numatec. Final parts will be ordered based on who is awarded the final fabrication.

\subsubsection{Fabrication / Construction}

Fluor Daniel Northwest will be responsible for fabrication and construction of prototype and the final design. 


\subsubsection{Prototype}

Fluor Daniel Northwest will control prototype equipment. The Engineer in charge will redline control of prototype fabrication drawings/sketches. Prototype testing and test results will be documented. The prototype information will be incorporated into this document.

\subsection{Discussion of Development}

A Lazy Susan style concept utilizes a rotating platform. Usually a bearing type device is utilized to allow for the rotation. In all the concepts considered, a bearing was used.

To develop these concepts, several bearing manufacturers were contacted. Each manufacturer suggested that a ceramic bearing rolling device should be based on the environmental requirements. They all suggested also that a single radial ball type bearing should be used.

The problem lies in that a ceramic ball is harder than the race material and thus a harder race material is required. Standard race material is hardened steel, which contains a higher carbon content. This type of steel tends to corrode in water. Use of other materials is too expensive for developing a bearing and manufacturers are not willing to build something that would meet the requirements.

A specialized bearing manufacturer (Champion) was contacted who builds bearing for outer space. Champion applies a dry lubricant to the bearing races through a sputtering technique. A 14 inch diameter steel (AISI 52100) bearing sputtered with silver and loaded with 122 ceramic balls was purchased from Champion at a real low cost for testing. The sputtering is expected to keep the corrosion from taking place.

Testing showed (see section 4.3 for more details) the first bearing obtained from Champion, did not work. It was discovered under a microscope that the balls were rubbing against each other and causing binding. A new bearing was then purchased from Champion with only 55 ceramic balls. This bearing would again use silver sputtered races but would also utilize spacers with a brass covering to keep the balls from binding. Lastly a plastic 
coating over the outside of the races was applied for corrosion control. This was the final bearing used.

\subsubsection{Sketches/Drawings}

All graphical depictions can be found in Appendix A

\section{Sketch 1}

This is a concept that would use a large diameter ring that contained several small radial bearings. The platform that would hold the basket would ride on the outer race of the radial bearings.

\section{$\underline{\text { Sketch } 2}$}

This is a concept that placed several balls in a large radial ring and the platform (the MCO Fuel Basket rests on) would rotate on top of the balls.

\section{Drawing 1}

This is a drawing showing how a radial bearing from Champion would be used. A holding block secures the outer race of the bearing and the inner race holds the platform that the basket can ride on.

\section{Final Drawing}

The final drawing will not be attached in this package but can be retrieved from the Hanford site document control using the following number: H-1-83990.

\section{Pictures}

Pictures were taken showing the final and tested design.

\subsection{Verification of Product Design}

All equipment developed was verified by either having an independent review, test specification, or calculations. The bearing and its assembly were verified through calculations followed by testing. Appendix A shows some pictures of testing.

A stress analysis calculation was done to verify the strength of the test stand and the table frame that supports the lazy susan with a basket fully loaded. A stress analysis calculation was done on the bearing to determine if failure would result from loading. All the calculations were independently reviewed and are attached in Appendix B. A discussion of the calculations is in section 4.3.1. Results from testing are discussed in 
section 4.3.2 and test documents are attached in the test specification Appendix $\mathrm{C}$ and the test report in Appendix D.

\subsubsection{Analysis}

All calculations were done as an intermediate verification step. Testing provided the final verification. The first calculation was done to determine if loading on the table frame would cause failure. The model was designed conservatively; for instance, gusset plates were left out and the applied load is greater than the actual by a factor of about 1.5. The results showed that a factor of safety of 2+ was achieved and no failure would occur.

A calculation was done to determine if the loading of the bearing would cause it to fail. Once again a conservative approach was made. First, an applied load of $5000 \mathrm{lbs}$. was applied instead of the actual load of about $3500 \mathrm{lbs}$. Then an additional factor of safety of 2 was applied to the individual load on each ball. The calculation was based on two assumptions: 1) failure would be primarily due to shear stress and, 2) and the ball contacts the surface by as much as $1 / 16^{\text {th }}$. The calculation showed that the bearing race would not fail.

\subsubsection{Testing}

Testing was the primary method used for verification. A test specification (attached in Appendix C) was written to establish what the lazy susan was tested for, how it was tested, conditions and equipment required for performing testing, and acceptance criteria/ data sheets used to document the tests. Ultimately testing was done to verify if the bearing would meet the requirements. A test report was written to document the results of the testing. It is listed in Appendix D.

The first bearing tested was a split bearing containing a full compliment of ceramic balls. The testing began and it was observed the bearing would easily turn under full load by simply pushing on it. However, after three to four turns, the bearing would bind and come to a stop. A grinding noise was also heard when it stopped turning. The bearing could be freed up by turning it the opposite way but again it would bind. It was also noted that there was heavy silver flaking due to the sputtering not sticking. 
Testing stopped on this bearing before putting it under water and the bearing was put under a microscopic evaluation. It was observed that there were perfect single scratches on each ball. It was concluded that the balls were binding and causing the scratches to themselves when forced. The races did not see any damage. This answer to the problem was affirmed after discussing it with Champion. The silver flaking was a result of poor application and surface preparation as was also so confirmed by Champion.

The second bearing was also obtained from Champion except it was modified to fix the problems encountered from the previous one supplied. This bearing used half as many balls as the first one and added separators to keep them from binding. The application of the silver lubricant was better such that there was no flaking even during dry testing. As a secondary precaution, the outer bearing portions were coated with a plastic for corrosive resistance.

Results from testing this bearing were that it passed every test and met the requirements. Data sheets in Appendix C clearly document this and the test report in Appendix D discusses the results in detail. The bearing was in the water for over a month. After removing the bearing from the water, it was examined and observed to still have no rust on it (except that which it received from the frame corroding). It still functioned seemingly effortlessly in its rotation. The testing also confirmed the calculations for loading such that it could take a load of $3400 \mathrm{lbs}$.

The Lazy Susans fabricated for-use were tested to see if they could be installed in the table located under water in the K Basin. The base plates were welded on using the test frame as the template. This verification was documented in the DynCorp work package 2H-99-03715 under a hold point.

\subsection{Conclusion}

The Lazy Susans fabricated for-use were constructed with on site fabrication services (DynCorp) under work package 2H-9903715. Two Lazy Susans were constructed but with different base plate attachments. One is to be used in the scrap loading station and the other is to be used in the loading station. Some minor modifications were made during fabrication that did not affect form or function and a non-conformance report was written against it (\#99-DYN/SFS-0019). The report was closed out before the work package was approved as complete. Three 
Fuel Retrieval System Small Tools Design Package

Lazy Susan

HNF-3525 Rev. 1

September 9, 1999

Page 9

engineering change notices were written against the drawing and they were incorporated in the final drawing revision. The final drawing number is $\mathrm{H}-1-83990 \mathrm{rev} 1$. 
Fuel Retrieval System Small Tools Design Package

Lazy Susan

HNF-3525 Rev. 1

September 9, 1999

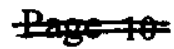

\section{Appendix A}

\section{Graphical Depictions of Product}


Fuel Retrieval System Small Tools Design Package

Lazy Susan

HNF-3525 Rev. 1

September 1, 1999

Page A- 1
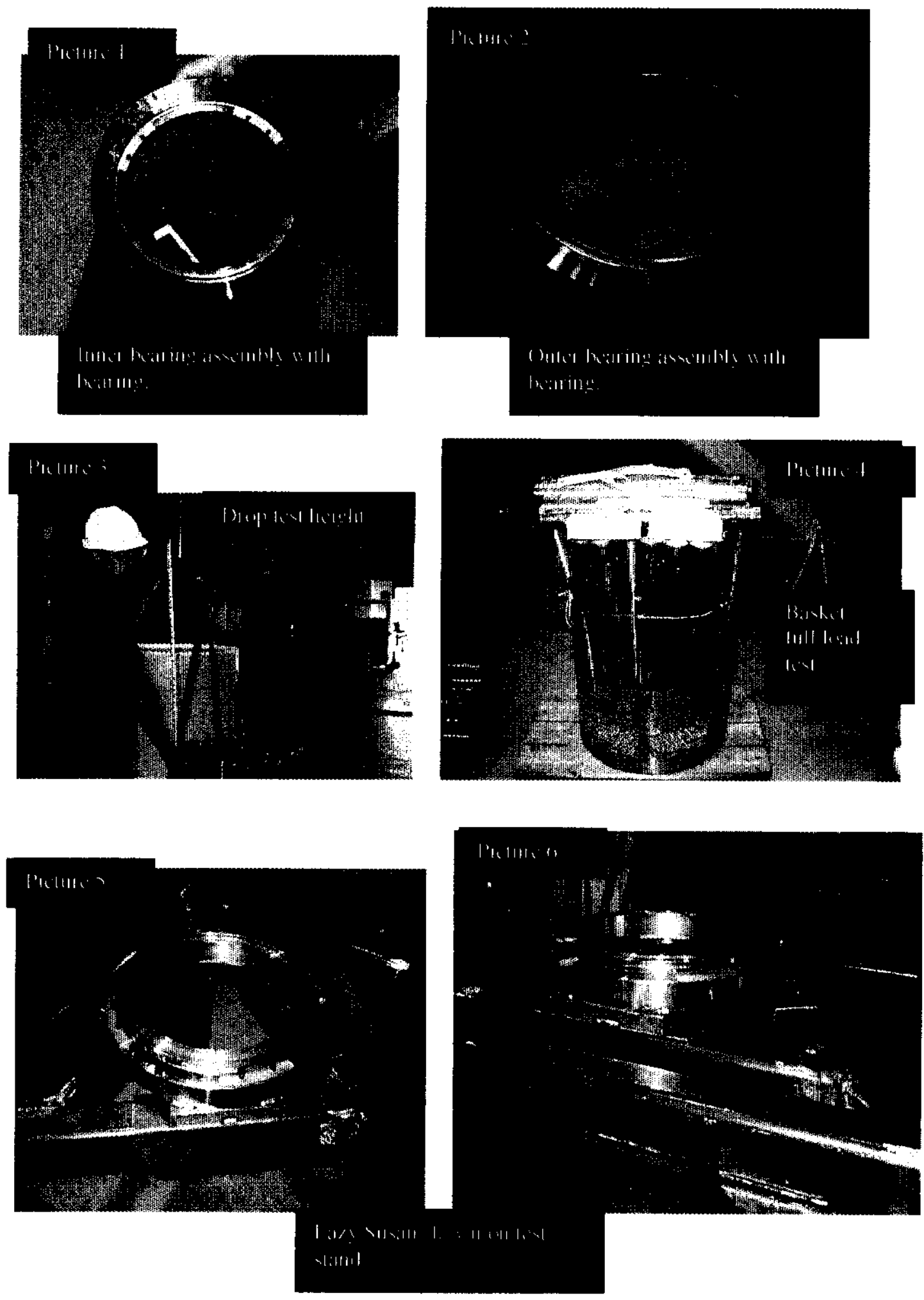


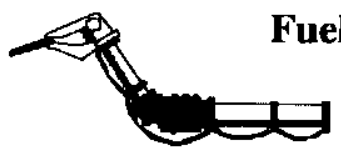

Fuel Retrieval System Small Tools Design Package

Lazy Susan

HNF-3525 Rev. 1

September 9, 1999

Page A-2
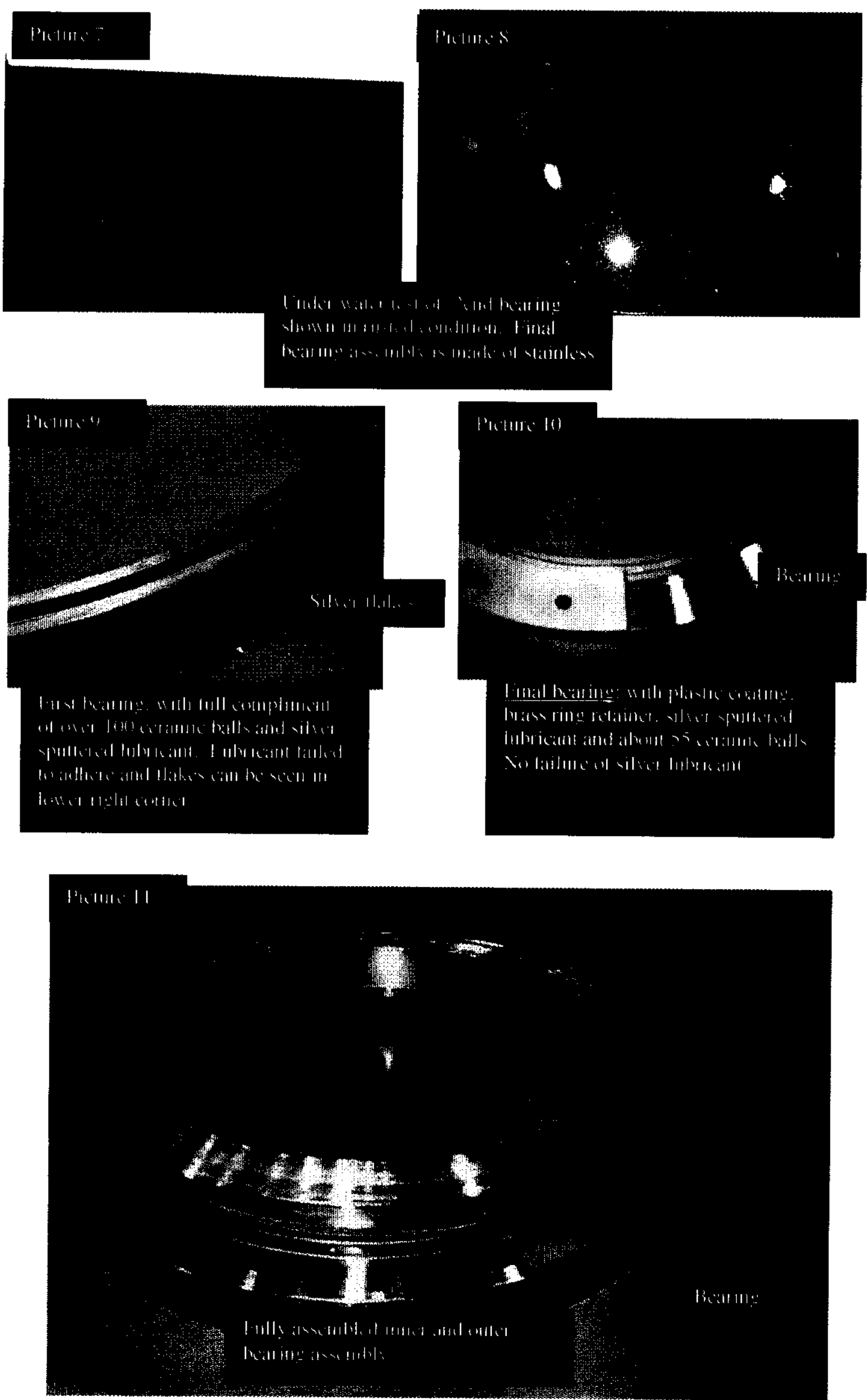


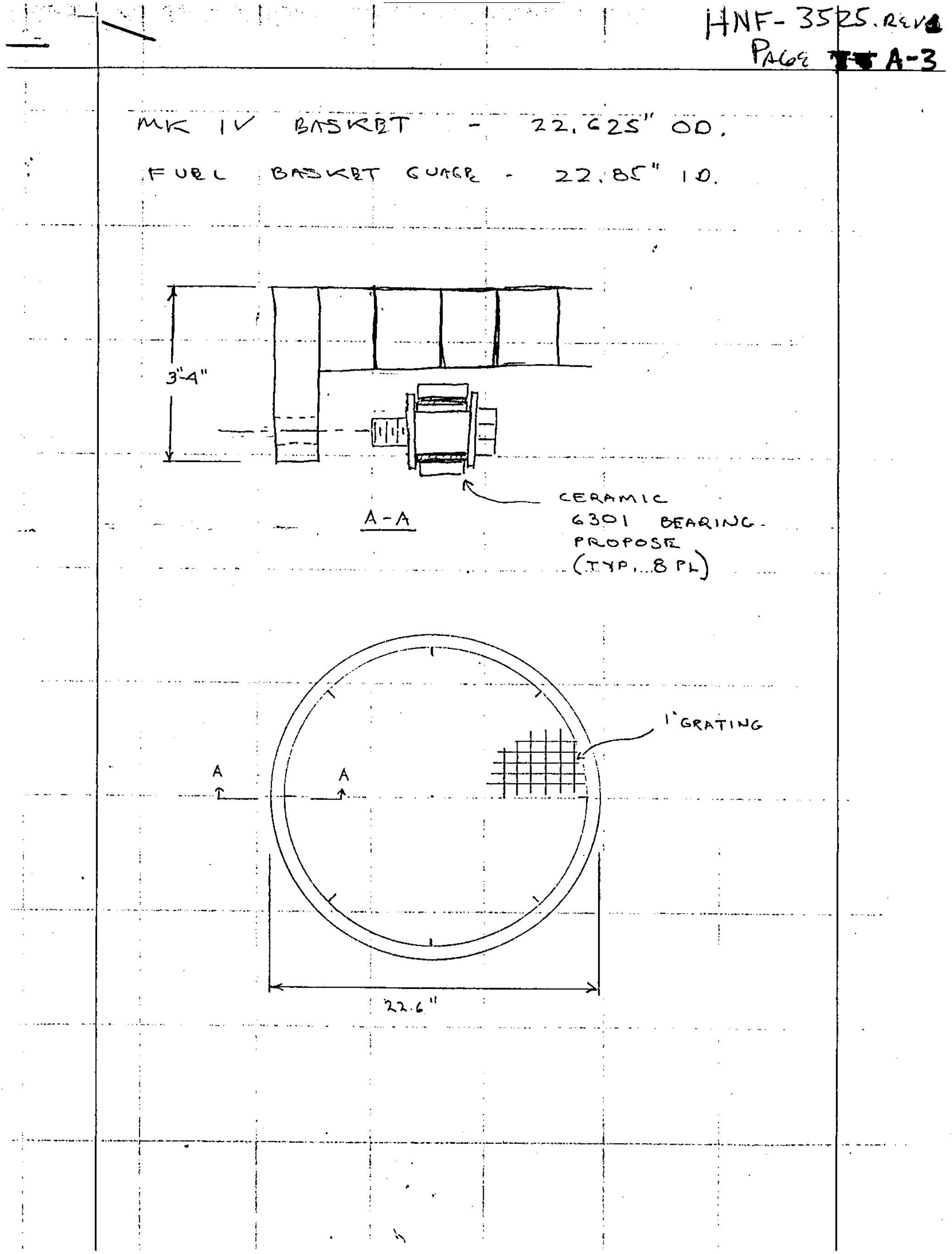




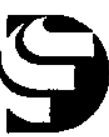

FLUOR DANIEL NORTHWEST, INC.

September 9, 1998

\section{SKETCHES OF LAZY SUSAN OPTION SECTIONS}
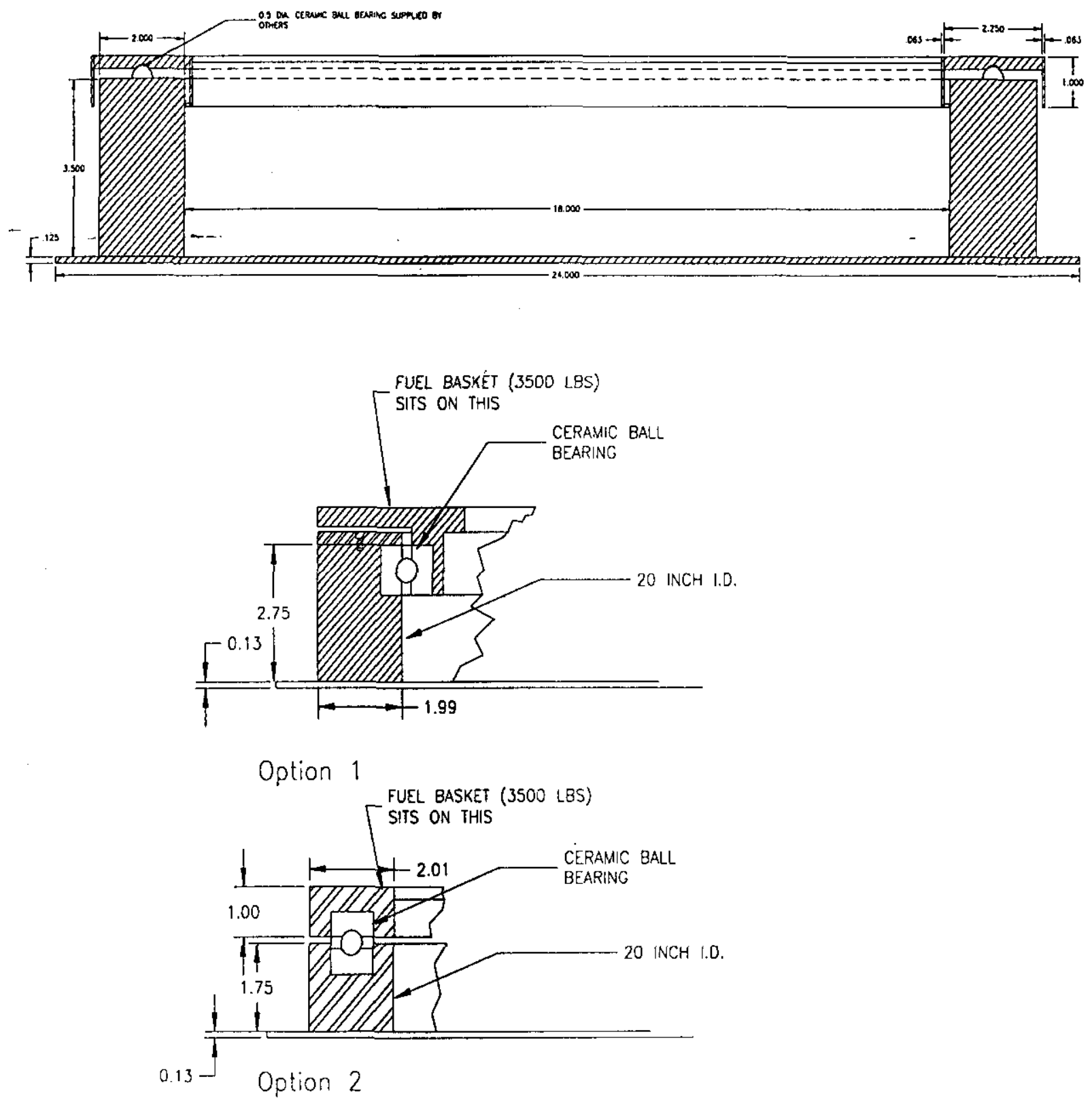
$H N F-3525$ Rav
paga

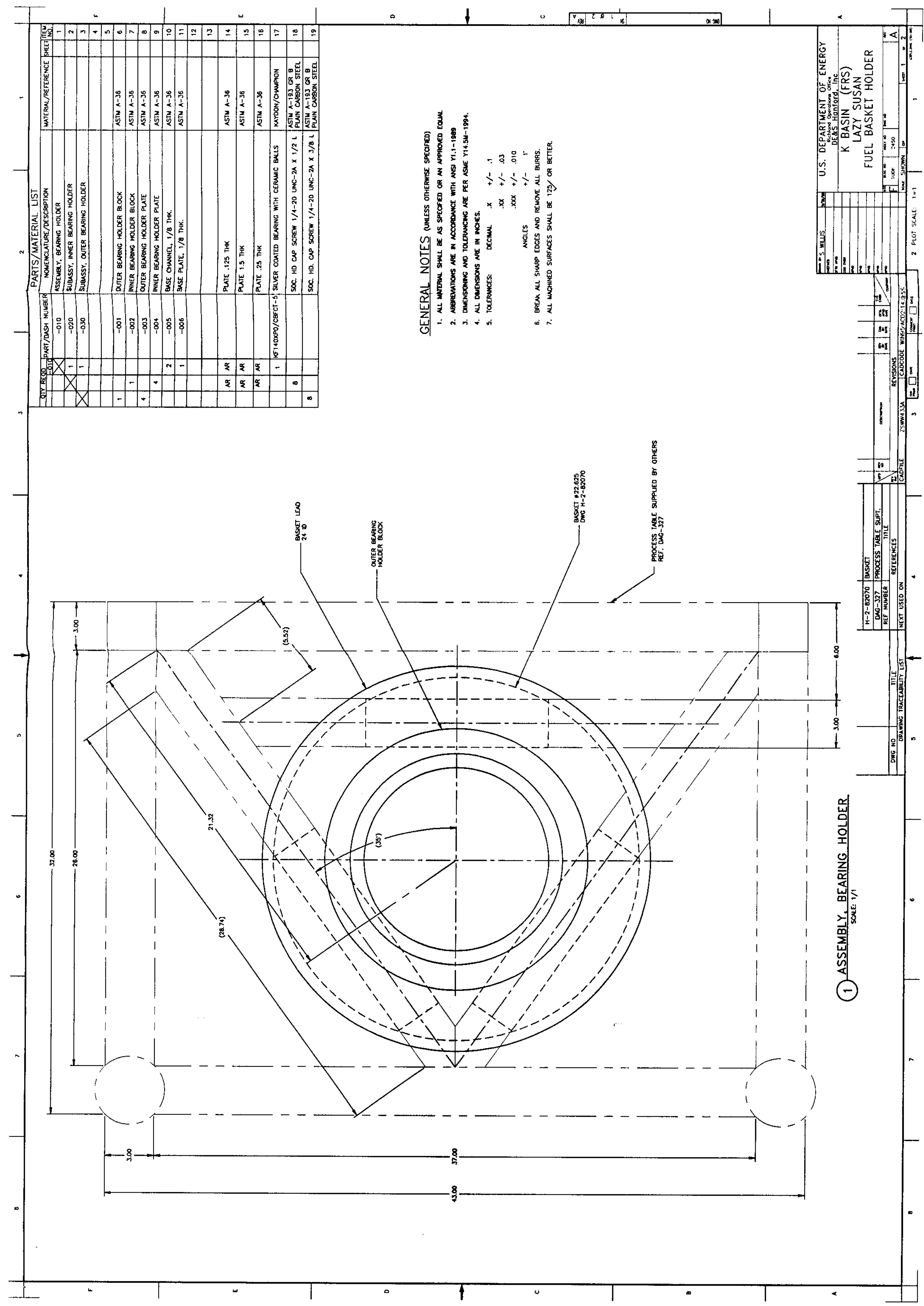


Fuel Retrieval System Small Tools Design Package

Lary Susan

HNF-3525 Rev. 1

September 9, 1999

E

Appendix B

Calculations 
Calc. No

Revision 0

Fluor Daniel Northwest

Page 1 of 5

DESIGN CALCULATION

\begin{tabular}{|c|c|c|}
\hline $\begin{array}{l}\text { Client : } \\
\text { Subject : }\end{array}$ & $\begin{array}{l}\text { Duke } \\
\text { Weld Verification for Lazy Susan Table }\end{array}$ & $\begin{array}{l}\text { WO/Job No } 65100101 \\
\text { Date } 9 / 17 / 98 \quad \text { By } \\
\text { Checked } 10 / 23 / 48 \text { By }\end{array}$ \\
\hline Location : & 100K Basin & Revised By \\
\hline
\end{tabular}

Problem: Verify tubing and its welding can support the weight of the lazy Susan and the basket filled with fuel rods.

Given:

Material is Carbon Steel Assume ASTM A36

Uitimate Strength: US: $58 \mathrm{ksi}$ (tension)

US : $=58000$

Yield Strength: YS: $36 \mathrm{ksi}$ (tension)

YS $:=36000$

YSs: 21 ksi (shear)

Mod of Elasticity: E: $29 \times 10^{6} \mathrm{psi}$

$\mathrm{YS}_{\text {shear }}:=21000$

\section{Sketches of structure being analyzed}

Weld Dimensions
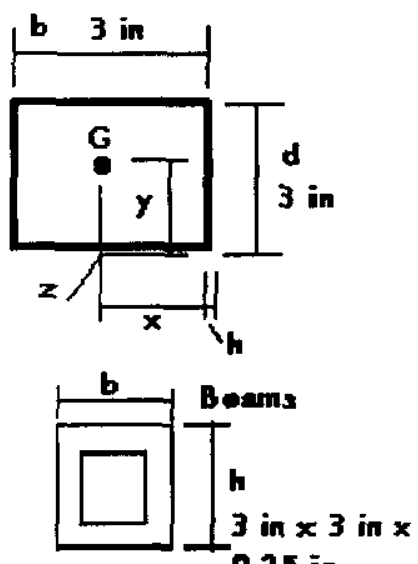

0.25 in

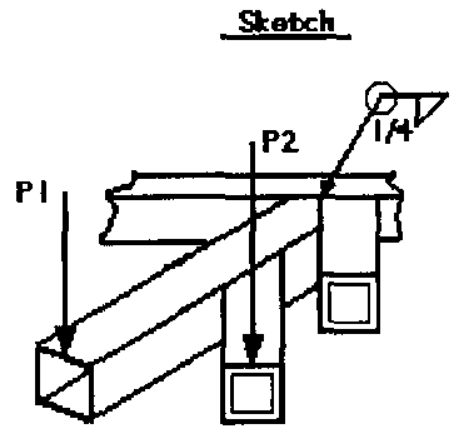

$P I=833 \mathrm{lbs}$

$P I=833$ ths 
Calc. No

Revision 0

Fluor Daniel Northwest

Page 2 of 5

\section{DESIGN CALCULATION}

\author{
Client : Duke \\ Subject : Weld Verification for Lazy Susan Table \\ Location : 100K Basin
}

\author{
WO/Job No 65100101 \\ Date 9/17/98 By \\ Checked 10/23/48 By \\ Revised \\ By D.J.Tedeschi \\ By
}

Solution: Verify tubing material and it's welds can support a $5000 \mathrm{lbs}$ weight distributed by bending and shear stress. Results should contain a factor of safety greater than 1 .

Assumptions:

a) Loading will be in bending

b) Overall load is $5000 \mathrm{lbs}$, supported by 3 members, the middle beam is really supported by the other two members.

c) To simplify the problem, the analysis will be on half of the long beam as shown in the sketch. thus the loading is as shown.

d) The allowable stress in tension is $60 \%$ of the Yield strength (21.6 ksi) and $40 \%$ for Shear strength (14.4 ksi)

Check for failure in the tubing:

For bending about the $\mathrm{x}$ or $\mathrm{y}$ axis:

tube
$b_{\text {outer }}:=3$
$\mathrm{h}_{\text {outer }}:=3$
$\mathrm{b}_{\text {inner }}:=2.5$
$\mathrm{h}_{\text {inner }}=2.5$
$\mathrm{c}:=\frac{1}{2} \cdot \mathrm{h}$ outer

dimensions

moment

of inertia

$I_{x y}=\left[\frac{1}{12} \cdot\left(b_{\text {outer }}\right)^{3} \cdot h_{\text {outer }}\right]-\frac{1}{12} \cdot\left(b_{\text {inner }}{ }^{3}\right) \cdot h_{\text {inner }}$

$\mathrm{I}_{\mathrm{xy}}=3.495 \mathrm{in}^{4}$

area

$$
\begin{aligned}
& A_{\text {tube }}=\left(b_{\text {outer }}{ }^{h} \text { outer }\right)-\left(b_{\text {inner }} \cdot h_{\text {inner }}\right) \\
& A_{\text {tube }}=2.75 \quad \mathrm{in}^{2}
\end{aligned}
$$

Free Body Diagram

12.13 in

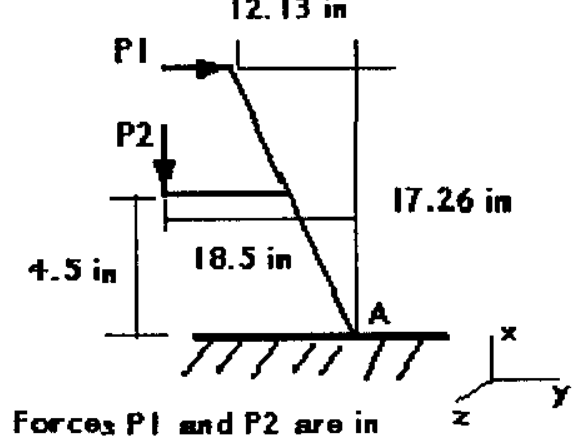

the negative $Z$ axis. 
DESIGN CALCULATION

Client : Duke

Subject : Weld Verification for Lazy Susan Table

Location : 100K Basin
WO/Job No 65100101

Date 9/17/98 By

Checked k/23/G\&By

Revised

Determining loading:

Overall load is $5000 \mathrm{lbs}$, each member supports $1 / 3$ of the weight. Therefore each member supports about $1667 \mathrm{lbs}$. Loads are reduced by $1 / 2$ when calculating since the beams are supported at both ends ( $833.5 \mathrm{lbs})$. The $3 \mathrm{rd}$ member will cause torque about the other two.

Forces

$\mathrm{P1}:=833.5$

$\mathrm{P} 2:=833.5$

Sum Loads about point $A$ as shown on the free body diagram.

$$
\begin{aligned}
& \sum P_{z}=P 1+P 2 \\
& \sum P_{z}=1.667 \cdot 10^{3} \mathrm{lbf}
\end{aligned}
$$

Moments about $\mathrm{A}$

$$
\begin{array}{ll}
x \text { axis } \quad & \mathrm{M}_{\mathrm{x}}:=(\mathrm{P} 1 \cdot 12.13)+(\mathrm{P} 2 \cdot 18.5) \\
& \mathrm{M}_{\mathrm{x}}=2.553 \cdot 10^{4} \mathrm{lbs} \text { in } \\
\mathrm{y} \text { axis } \quad \mathrm{M}_{\mathrm{y}}:=(\mathrm{P} 1 \cdot 17.26)+(\mathrm{P} 2 \cdot 4.5) \\
\mathrm{M}_{\mathrm{y}}=1.814 \cdot 10^{4} \quad \text { lbs in } \\
\text { Loading in shear } \\
\lambda_{\text {tube }}=\frac{\sum \mathrm{P}_{\mathrm{z}}}{\mathrm{A}_{\text {tube }}} \\
\lambda_{\text {tube }}=606.182 \quad \mathrm{psi}
\end{array}
$$

Loading due to bending

$$
\begin{aligned}
x \text { axis } \quad \sigma_{x}:=\frac{M_{x} \cdot c}{I_{x y}} \\
\sigma_{x}=1.096 \cdot 10^{4} \quad p s i
\end{aligned}
$$


Calc. No

Revision 0

Fluor Daniel Northwest

Page 4 of 5

DESIGN CALCULATION

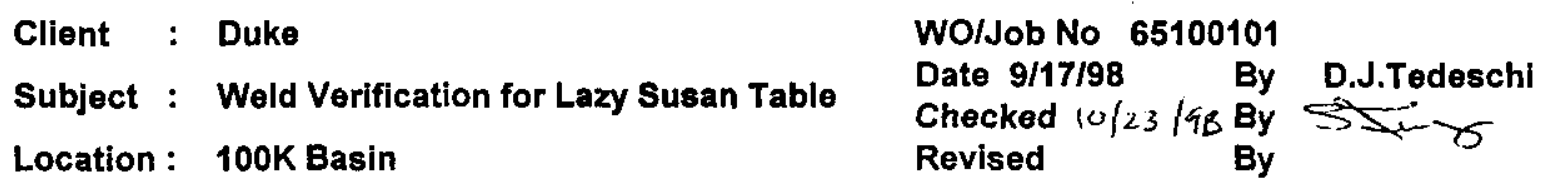

$y$ axis

$$
\begin{aligned}
& \sigma_{y}:=\frac{M_{y} \cdot c}{I_{x y}} \\
& \sigma_{y}=7.785 \cdot 10^{3} \quad \text { psi }
\end{aligned}
$$

Summation of stress at point $A$

$$
\begin{aligned}
& \Sigma \sigma:=\left(\sigma_{x}{ }^{2}+\sigma_{y}{ }^{2}+\lambda_{\text {tube }}{ }^{2}\right)^{\frac{1}{2}} \\
& \Sigma \sigma=1.346 \cdot 10^{4} \quad \mathrm{psi}
\end{aligned}
$$

Solve for the factor of safety:

$\mathrm{n}_{\text {tube }}:=\frac{Y S}{\Sigma \sigma}$

$\mathrm{n}_{\text {tube }}=2.676 \begin{aligned} & \text { The overall stress when compared to the yield stress of the tubing } \\ & \text { results in a factor of safety of } 2.6 \text { which is acceptable and therefore tube }\end{aligned}$ will not fail.

Check stress for welds at point $A$ as shown in the sketches and freebody diagram:

Assume weld pattern as shown in the previous sketch.

This is a similar pattern for calculations but is not much different.

Welds are $1 / 4$ fillets.

thickness

$\mathrm{h}=.25 \quad \mathrm{~d}_{\text {outer }}=3$

of weld

Welds in shear

weld area

$A_{w}=1.414 \cdot h \cdot\left(b_{\text {outer }}+d_{\text {outer }}\right)$

$\mathrm{A}_{W}=2.121 \quad \mathrm{in}^{2}$

Shear

$$
\begin{aligned}
& \lambda_{\text {shear }} \frac{\sum \mathrm{P}_{\mathrm{z}}}{\mathrm{A}_{\mathrm{w}}} \\
& \lambda_{\text {shear }}=785.95 \mathrm{psi}
\end{aligned}
$$

$$
B-4
$$




\section{DESIGN CALCULATION}

$\begin{array}{llll}\text { Client }: \text { Duke } & \text { WO/Job No 65100101 } \\ \text { Subject : } & \text { Weld Verification for Lazy Susan Table } & \begin{array}{l}\text { Date 9/17/98 } \\ \text { Checked } 10 / 23 / 98\end{array} \text { By D.J.Tedeschi } \\ \text { Location : } & \text { 100K Basin } & \text { Revised } & \text { By }\end{array}$

$$
\begin{aligned}
& \text { Stress due to bending: } \\
& I_{\text {xyweld }}:=0.707 \cdot h \cdot \frac{d_{\text {outer }}^{2}}{6} \cdot\left(3 \cdot b_{\text {outer }}+d_{\text {outer }}\right) \\
& I_{\text {xyweld }}=3.181 \\
& \text { x axis } \quad \sigma_{\text {xweld }}:=\frac{M_{x} \cdot \frac{d_{\text {outer }}}{2}}{I_{\text {xyweld }}} \\
& \sigma_{\text {xweld }}=1.204 \cdot 10^{4} \\
& \text { y axis } \quad \sigma_{\text {yweld }}=\frac{M_{y} \cdot \frac{d \text { outer }}{2}}{I_{x y w e l d}} \\
& \sigma_{\text {yweld }}=8.551 \cdot 10^{3} \text { psi }
\end{aligned}
$$

Summation of overall stress:

$$
\begin{aligned}
& \sum \sigma_{\text {weld }}=\left(\sigma_{\text {xweld }}{ }^{2}+\sigma_{\text {yweld }}{ }^{2}+\lambda \text { shear }^{2}\right)^{\prime} \\
& \sum \sigma_{\text {weld }}=1.479 \cdot 10^{4} \mathrm{psi} \\
& n=\frac{Y S}{\sum \sigma_{\text {weld }}} \\
& n=2.435 \quad \text { The overall stress when c }
\end{aligned}
$$

The overall stress when compared to the yield stress of the weld results in a factor of safety of 2.4 which is acceptable and therefore welds will not fail.

$$
B-5
$$


HNF-3525 rev

Talc. No

Revision 0

Fluor Daniel Northwest

Page 1 of 2

DESIGN CALCULATION

Client : Fluor Daniel Hanford

Subject : Lazy Susan Bearing Calculation

Location : 100K Basin
WO/Job No 65100331

Date $3 / 31 / 99$ By

Checked $8 / 3 / 144$ By

Revised By
D.J.TedeschiDf Coded

RERusiet

Problem: Verify weight of loaded fuel basket will be can be supported by bearing with out deforming it.

Given: An assumption of $5000 \mathrm{lbs}$. will be used for the fully loaded basket (actual is 3500 ).

Bearing material is made of carbon steel AISI 52100 .

Ceramic ball is a rigid structure and steel will deform before the ball will reach its yield stress

There are 55 balls in the bearing.

Solution: Bearing material: Yield $\mathrm{Y}_{\mathrm{S}}:=50000 \mathrm{psi} \quad \mathrm{U}_{\mathrm{S}}:=92000 \mathrm{psi} \quad \mathrm{FS}:=2$ factor of safety

Weight per ball: $\quad \mathrm{W}_{\text {ball }}:=\frac{5000}{55}$

When the total weight is divided by the number of balls, the result is the maximum loading a single ball will apply to the bearing race.

$$
\begin{aligned}
{ }^{*} \mathrm{~W}_{\text {ball }} & =90.909 \\
\mathrm{~F}_{\text {ball }} & =\mathrm{W}_{\text {ball }} \mathrm{FS} \\
\mathrm{F}_{\text {ball }} & =181.818 \quad \mathrm{lbs}
\end{aligned}
$$

See the following diagrams for details on dimensions of the bearing.

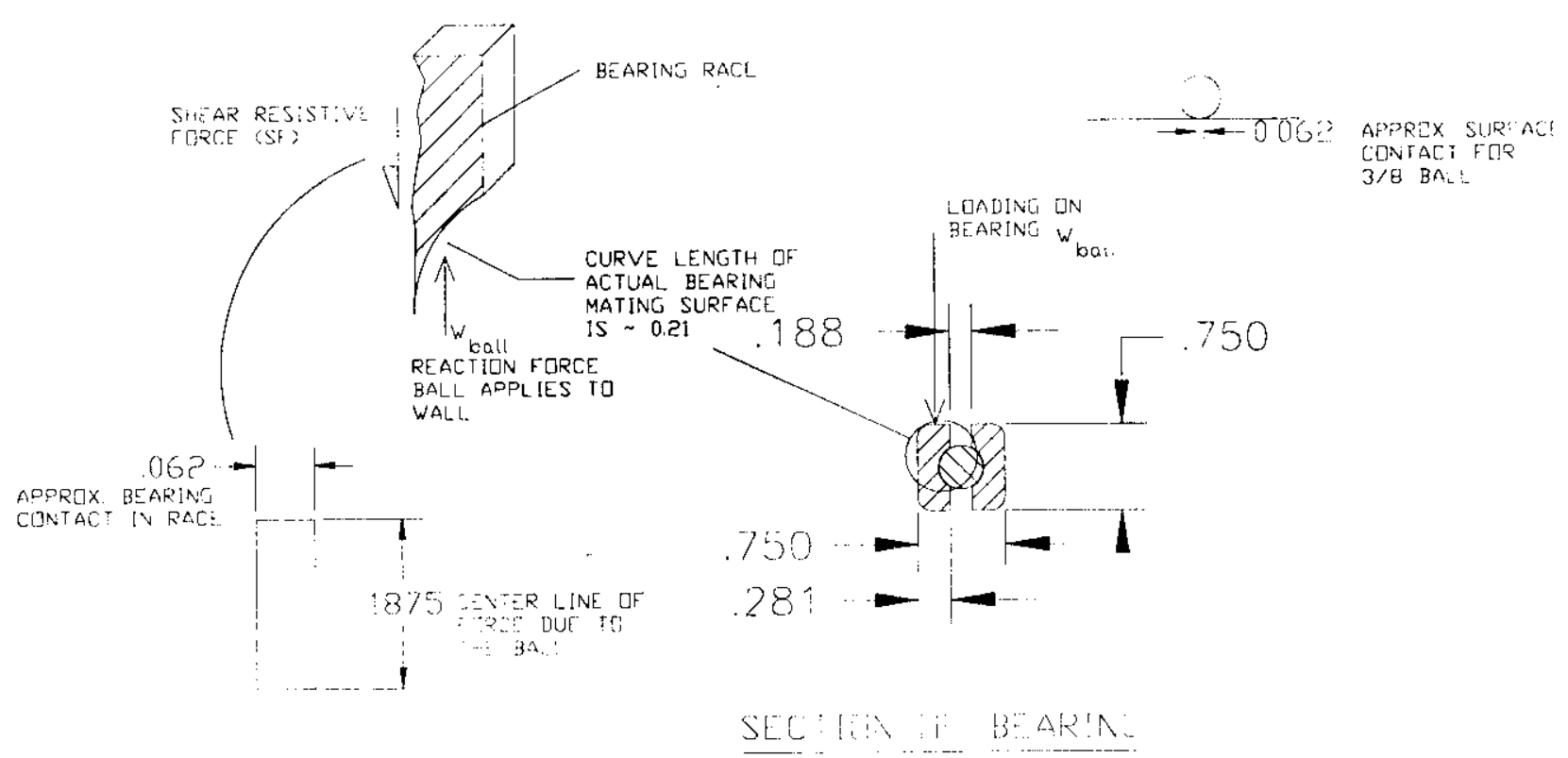

APPENDIX B-6 
Calc. No

Revision 0

Fluor Daniel Northwest

Page 2 of 2

\section{DESIGN CALCULATION}

Client : Fluor Daniel Hanford

Subject : Lazy Susan Bearing Calculation

Location : $100 \mathrm{~K}$ Basin
WOIJob No 65100331

Date B. $3, k_{4} \%$ By

Checked 8/3//49 By

Revised
D.J.Tedeschi Dif Teolede

$R E R$ muld

Assume a downward $5000 \mathrm{lb}$ force is applied due to loading of the basket on the inner part

of the bearing. An opposite upward reactive force is then applied to the outer bearing race via the ball.

Assume shear stress will be the force which would caused failure and therefore all others would be minimal in comparison. Hence only shear stress will be calculated.

Assume ball applies a concentrated load on surface area of $.062^{\prime \prime}$ wide $\times .1875^{\prime \prime}$ along the curve (see figure).

Area of shear stress: $A_{\lambda}:=.062 \cdot .1875$

$$
\mathrm{A}_{\lambda}=0.012 \mathrm{in}^{2}
$$

Shear stress:

$$
\begin{aligned}
& \lambda:=\frac{F_{\text {ball }}}{A_{\lambda}} \\
& \lambda=1.564 \cdot 10^{4} \quad \text { psi }
\end{aligned}
$$

Assume allowable shear stress of bearing race material is equal to $50 \%$ of the material's allowable yield.

$$
\begin{aligned}
& \lambda_{\mathrm{al}}=\mathrm{Y}_{\mathrm{s}} \cdot 5 \\
& \lambda_{\mathrm{al}}=2.5 \cdot 10^{4} \quad \mathrm{psi}
\end{aligned}
$$

Actual shear is less than the allowable shear: $\lambda<\lambda$ al

therefore, bearing will be able to hold the weight without deformation to the race 


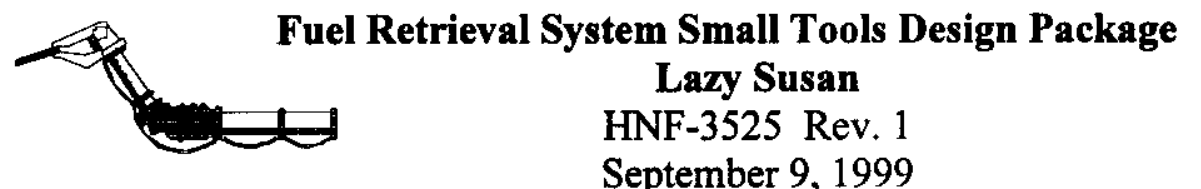

September 9, 1999

Page-12

\section{Appendix C}

\section{Test Specifications}




\subsection{PURPOSE}

The purpose of this test specification is to verify the operability of a "Lazy Susan" design used to aid operations in the loading of fuel elements into a MCO fuel basket. This specification involves several individual verifications, in which each one is performed sequentially such that the bearing must pass the first verification before proceeding to the second one. All verifications listed will be done through testing. The following is the sequential list of verifications that describe the purpose for each test:

\section{Verification - 1}

The first verification will be to verify the Lazy Susan will not fail from stress induced by a static load ranging from a of a fully loaded basket (approximately $3200 \mathrm{lbs}$.) to a design load of $3400 \mathrm{lbs}^{*}$.

\section{Verification - 2}

The second verification will be to verify the Lazy Susan will not fail due to stress induced from an impact load. The test will be to drop a single fuel assembly dropping from three feet above and on top of a fully loaded MCO Fuel Basket positioned on the Lazy Susan.

\section{Verification - 3}

The third verification will be to verify if the Lazy Susan can freely rotate with minimal effort from the Konan arm first by having an offset load and a full uniform load on it. The loading will be achieved by using a MCO Fuel Basket with dummy fuel assemblies loaded in it. The offset load will load $1 / 4$ of the basket (pie shape) to simulate typical Operations loading methods.

\section{Verification -4}

The forth verification will be to verify the Lazy Susan can operate under the deionized water conditions consistent with $\mathrm{K}$ Basin water. This is accomplished by repeating the tests listed in the previous verification (3) with the exception that the Lazy Susan has been submersed in deionized water for a period of about 200 hours.

\section{APRENDIX $C-1$}

\footnotetext{
* Design Load has changed from 5000 lbs to 3400 lbs per telecon with Bruce Groth the Design Authority
} 


\section{Verification - 5}

The fifth verification will be to verify long term operation of the Lazy Susan while under deionized water. This is accomplished by testing the Lazy Susan for a period of 3 to 6 months using K Basin Operation's training on the Konan.

\section{$2.0 \quad$ TEST DESCRIPTION}

All tests will verify the Lazy Susan design as shown in the drawing section of HNF-3525, Fuel Retrieval System Small Tools Design Package Lazy Susan. Each test will have the Lazy Susan sit on a mock up of the support table frame (depicted in Westinghouse of Carlsbad, New Mexico, drawing number DAG-327) and have a MCO Fuel Basket (depicted in Department of Energy Hanford drawing H-2-828060) sit on the Lazy Susan. All verifications and visual observations will be recorded in a test log and assembled in a test report. Verifications and observations will be logged in section 8.0 of this document. Pictures will be taken as necessary. This document and final test report will be incorporated into HNF-3525 upon completion of testing.

The following are descriptions of each verification test:

\section{Verification -1}

Preweighted dummy fuel assemblies are loaded into the MCO Fuel Basket until basket is fully loaded. Visual observations of the Lazy Susan's response to the loading are made. The basket will then be removed, and the bearing is visually examined for any stress damage. The inner bearing is hand rotated to verify if it still rotates. With the basket fully loaded, it is placed back on the Lazy Susan. Weights are uniformly distributed on top of the basket until a total of $3400 \mathrm{lbs}$. (weights + dummy fuel assemblies + MCO Fuel basket $=3400 \mathrm{lbs}$.) are achieved. Visual observations again are made of the Lazy Susan and frame as the weight increases. The loaded basket and added weights are again removed and the bearing is examined for any stress damage. The inner bearing is hand rotated to verify if it still rotates.

\section{Verification -2}

With the MCO Fuel Basket fully loaded and on the Lazy Susan, a dummy fuel assembly is dropped on top of the basket from a distance of 3 feet. The basket will then be removed from the Lazy Susan. The bearing will then be visually examined for any stress damage and hand rotated to verify it still rotates. 


\section{Verification - 3}

With the MCO Fuel Basket placed on the Lazy Susan, the basket is loaded with dummy assemblies $1 / 4$ of the way (pie shape) consistent with Operation's method. The basket is then rotated 10 full revolutions using Konan and ease of rotation is verified. Then the basket is fully loaded and rotated 10 full revolutions again using Konan and the ease of rotation is verified. Ease of rotation will be noted on both cases.

\section{Verification -4}

The Lazy Susan is submersed in deionized water comparable in properties to the basin water for 200 hours. Once the bearing is placed in water, it will not be removed in order to accurately represent the operating conditions. This submersion will take place in the vicinity of Konan arm. Preferably, the Lazy Susan/frame and water blanket will be located where the processing table contains it. After the 200 hours, the Lazy Susan will be visually examined for corrosion. Repeating verification \# 3 will test for the effects of corrosion on the Lazy Susan.

\section{Verification -5}

Operations will continue to train with the Lazy Susan under the conditions listed in the previous verification (verification \# 4). Biweekly observations of the Lazy Susan's operability will be made for a period of 3 to 6 months.

\subsection{CONDITIONS FOR TESTS}

Testing will be done in the 305 facility located in the Hanford 300 Area. The facility will have to accommodate lifting of $3500 \mathrm{lbs}$. The facility will have to supply continuos filtered deionized water with physical properties matching that of the K Basin's water. The exception to this is the water temperature of which it must be with in $30^{\circ} \mathrm{F}$.

\subsection{REQUIRED SUPPORT}

\subsection{MANAGEMENT OF TEST}

Fluor Daniel Northwest Engineer will be responsible as the test engineer. Numatec will be responsible for providing support to testing through technician support. This support will include fabrication, erection, and minor operations of the testing apparatus. $\mathrm{K}$ Basin Operations will provide Konan operating support.

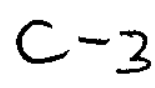


This document will not be incorporated into HNF-3525 until completion of verification \# 4. A master copy of this document will be used for testing and will be controlled by the test engineer. Changes will be made only by the approval of the test engineer using redlines, their signature, and date of change.

\subsection{EQUIPMENT}

- $\quad$ Tube frame used for supporting the Lazy Susan constructed to the dimensions of the process table in drawing DAG-327

- $\quad$ Lazy Susan designed as specified by the drawing listed in HNF-3525

- Water container large enough to engulf the Lazy Susan

- $\quad 55$ weighted dummy fuel assemblies (50-55 lbs./assembly)

- MCO Fuel Basket (what's available)

- $\quad$ Enough weights to make up the $3400 \mathrm{lb}$. difference

- $\quad$ Filtered deionized water with physical properties equivalent to the $\mathrm{K}$ Basin water

- Digital or film based camera

- Konan robotic arm

- Miscellaneous support tools (hammers, screw drivers,...)

\subsection{ACCEPTANCE CRITERIA AND DATA REQUIRED}

\section{Verification - 1}

Bearing and Lazy Susan metal shall not exceed its yield strength such that permanent damage occurs and impairs the operability of the bearing. Stress damage is assumed if the following is present: 1) material is warped, bent, deformed, or stretched, 2) material has cracks or is broken, and 3) a discoloration has occurred in the material (metal will usually lighten up).

\section{Verification - 2}

Bearing and Lazy Susan must be able to withstand impact loading such that permanent damage does not occur and impair the operability of the bearing.

\section{Verification - 3}

Lazy Susan must be able to rotate freely without hindrance or excessive strain to Konan. Lazy Susan must not be too loose such that it is hard to stop it from rotating. Acceptance of this will be subjective to K Basin's Operator opinion. Actual forces required to start the rotation of the Lazy Susan maybe measured upon request.

\section{Verification -4}

Lazy Susan must be able to rotate freely without hindrance or excessive strain to Konan. Presence of water shall not cause failure of bearing operation. Acceptance of this will be subjective to K Basin's Operator opinion. Actual

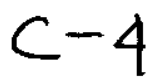


forces required to start the rotation of the Lazy Susan maybe measured upon request.

Verification - 5

Lazy Susan must be able to rotate freely without hindrance or excessive strain to Konan for the period of operation. Corrosion of Lazy Susan shall not exceed the design life of 3 years. An extrapolation will have to be made of estimated rate of corrosion based on the hours of operation it is immersed.

\subsection{SAFETY AND PRECAUTIONS}

Care should be taken when lifting Lazy Susan. Mechanical methods should be used when feasible to lift components such as weights and dummy fuel elements because they can weight $50 \mathrm{lbs}$. or more.

\subsection{TEST PREDICTIONS}

It is expected that the Lazy Susan should be able to hold the weight and not fail due to stress. Previous tests on a smaller bearing in water showed that corrosion took place. It is expected that bearing will corrode but not fail. 
FRS Test Specification for the Lazy Susan

HNF-3525 Rev. $\not 1$

March 22, 1999

Page 6

8.0 OBSERVATIONS

ORIGINAL

Verification 1 - Bearing WiTH full compliment

Evaluation 1

Date of test: 3/22/9S. Technician: R. A. Spare Rate RL Engineer: DAviD TEDEsch1-D/Redech.

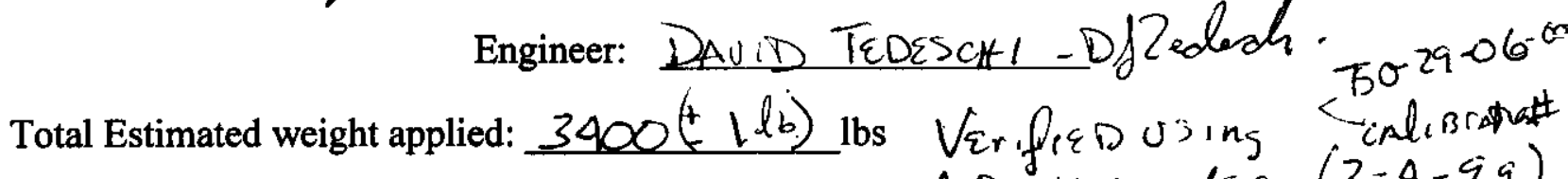
A DyNamomatis. $-(3-4-99$.

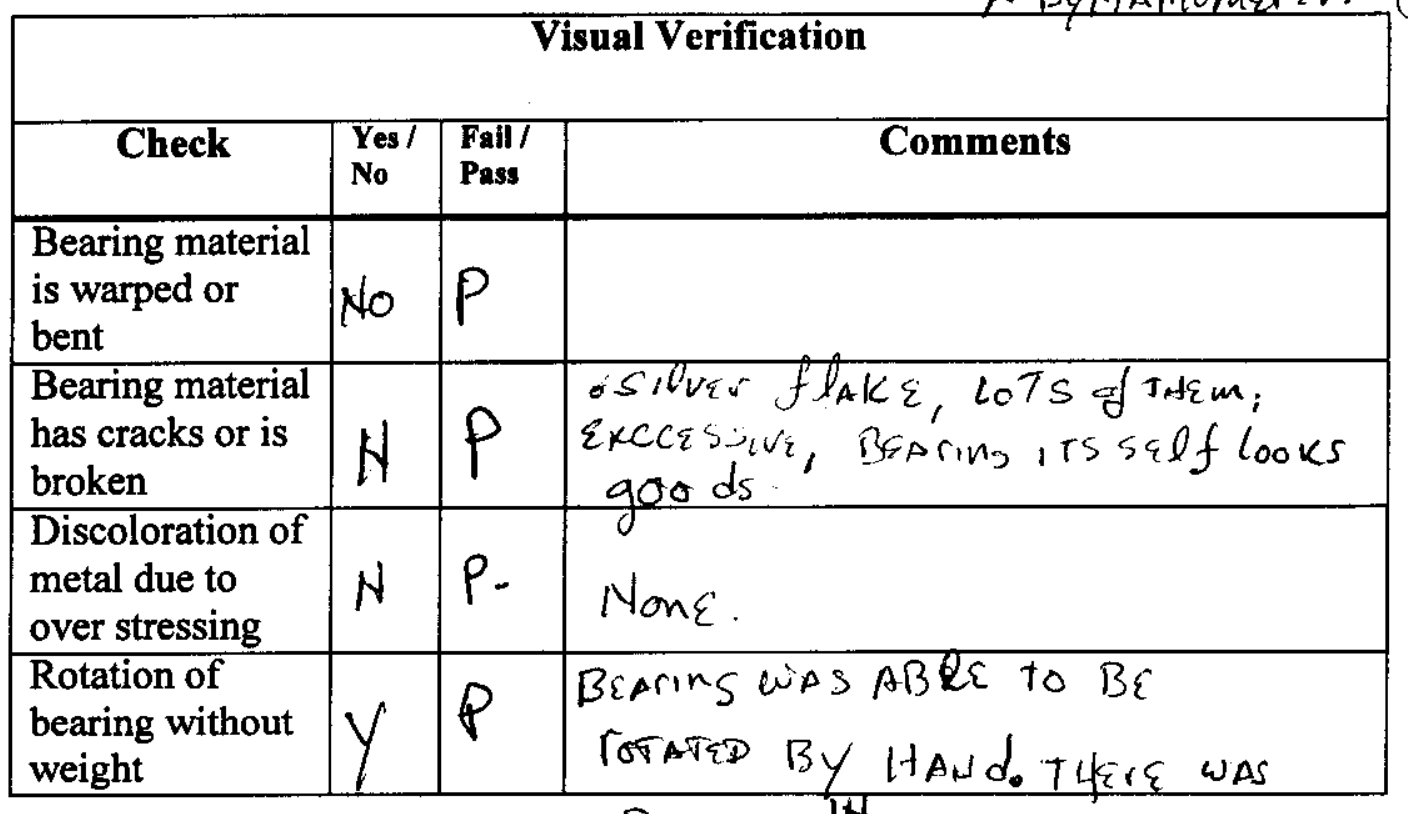

DynAfor - 4000 lbs

Test Deviations:

ADDricancel Binding

- Full weight was applied.

$c-6$ 
Verification 2 - Baaring $w$, th full complimant

\section{Evaluation 2}

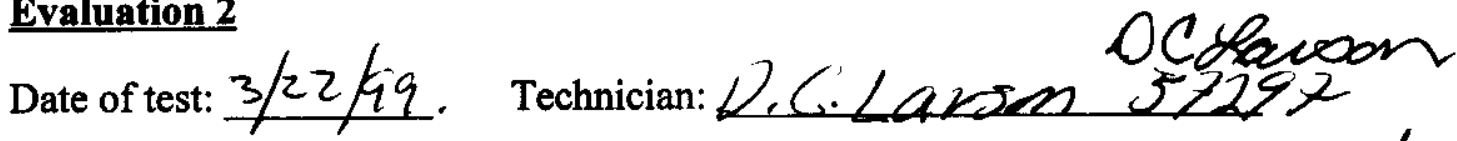
Engineer: David TeDescits DJ Redesoh. Total Estimated weight applied: 2990 lbs - Dropped SOlbload

\begin{tabular}{|c|c|c|c|}
\hline \multicolumn{4}{|c|}{ Visual Verification } \\
\hline Check & \begin{tabular}{|l} 
Yes/ \\
No
\end{tabular} & $\begin{array}{l}\text { Fail I } \\
\text { Pass }\end{array}$ & Comments \\
\hline $\begin{array}{l}\text { Bearing material } \\
\text { is warped or } \\
\text { bent }\end{array}$ & $M$ & P & T \\
\hline $\begin{array}{l}\text { Bearing material } \\
\text { has cracks or is } \\
\text { broken }\end{array}$ & 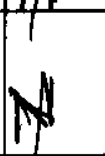 & P & \\
\hline $\begin{array}{l}\text { Discoloration of } \\
\text { metal due to } \\
\text { over stressing }\end{array}$ & $N$ & 8 & \\
\hline $\begin{array}{l}\text { Rotation of } \\
\text { bearing with out } \\
\text { weight is still ok }\end{array}$ & $y$ & $P$ & wisthrout weighton it \\
\hline
\end{tabular}

Test Deviations:

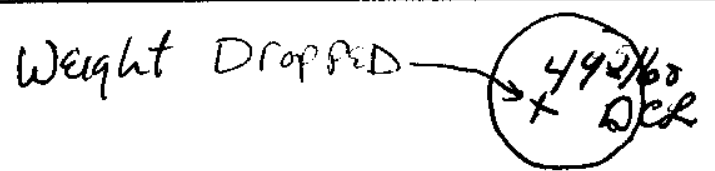


FRS Test Specification for the Lazy Susan HNF-3525 Rev. $\not$ I

March 22, 1999

Page 8-

Verification 3 -Bating with full complement.

Evaluation 3

ORIGINAL

Date of test: $3 / 23$

Technician: Route 7 Spock RS

Engineer:DAUD TeDeschl D) Zeckech

Total Estimated weight applied when $1 / 4$ loaded: 1160 lbs $\sim$ Rough 10 cilamuts Total Estimated weight applied when fully loaded: 3000 lbs WITHA liADBi

\begin{tabular}{|l|l|l|l|}
\hline \multicolumn{3}{|c|}{ Visual Verification } \\
\hline \multicolumn{1}{|c|}{ Check } & $\begin{array}{l}\text { Yes / } \\
\text { No }\end{array}$ & $\begin{array}{l}\text { Fail I } \\
\text { Pass }\end{array}$ & \\
\hline $\begin{array}{l}\text { Bearing freely } \\
\text { rotates with 1/4 } \\
\text { load by a man } \\
\text { pulling on it }\end{array}$ & Comments & & Tire is Binding in on s A R\&A \\
\hline $\begin{array}{l}\text { Bearing freely } \\
\text { rotates fully } \\
\text { loaded by a man } \\
\text { pulling on it }\end{array}$ & $Y$ & P & \\
\hline $\begin{array}{l}\text { Bearing freely } \\
\text { rotates with 1/4 } \\
\text { load by Koran } \\
\text { pulling on it }\end{array}$ & & & \\
\hline $\begin{array}{l}\text { Bearing freely } \\
\text { rotates fully } \\
\text { loaded by } \\
\text { Konan pulling } \\
\text { on it }\end{array}$ & & & \\
\hline $\begin{array}{l}\text { Force required } \\
\text { to rotate the } \\
\text { bearing }\end{array}$ & & & \\
\hline
\end{tabular}

Test Deviations:

Stopped FaST

$c-8$ 
FRS Test Specification for the Lazy Susan HNF-3525 Rev. $\not 1$

April 15, 1999

ORIGINAL

Pager

8.0 OBSERVATIONS

Verification 1 2CND BeAring WITH SËfACATOrS.

Evaluation 1

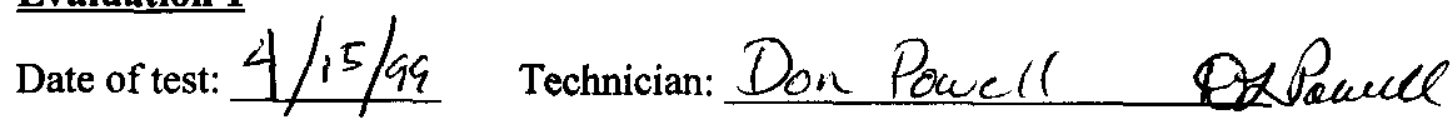
Engineer: DaviD TEDescidi Do Tecleade. Total Estimated weight applied: 3404 lbs

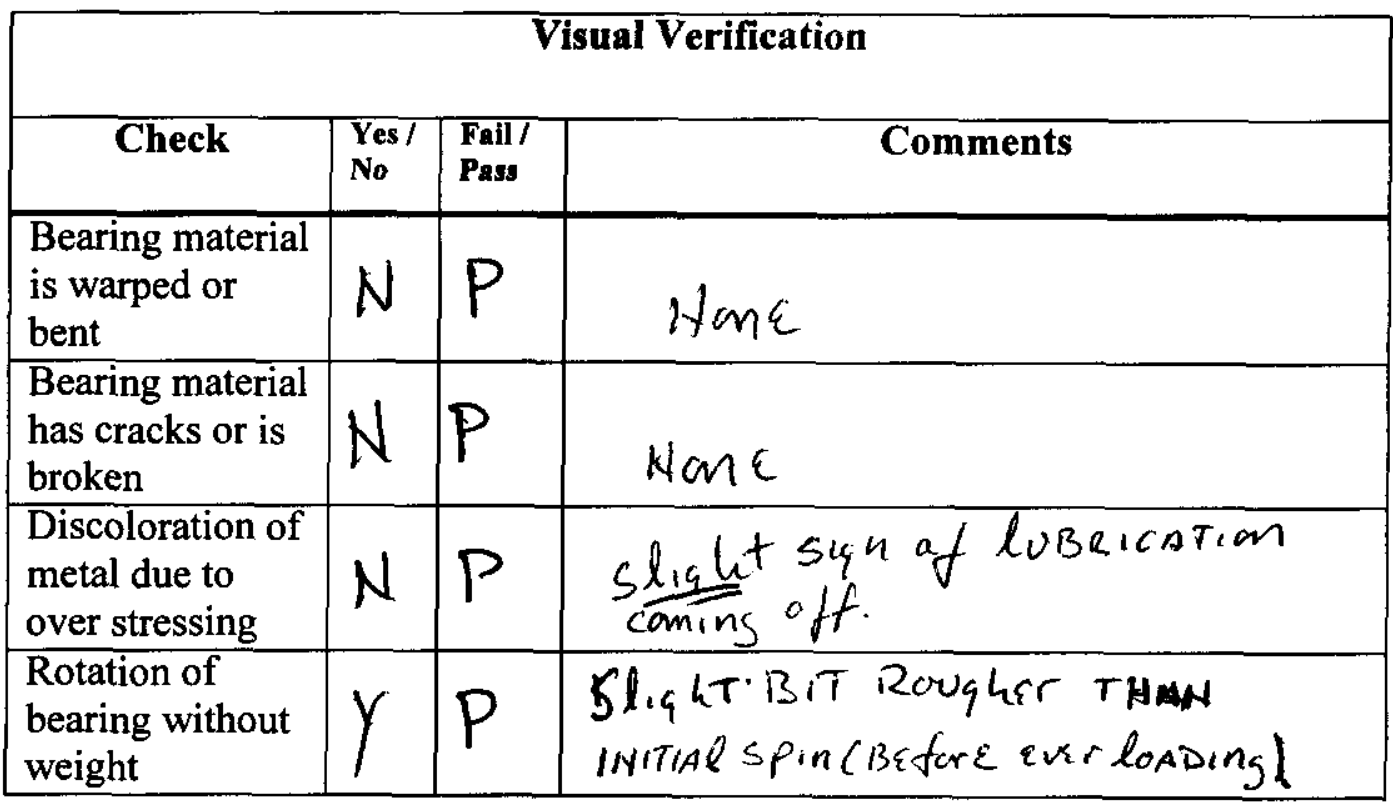

Test Deviations:

None

Dynamomatar used for all tests was calibrates

\# TS0-29-06-0.4(3-4-99)-4000lb

$c-9$ 
FRS Test Specification for the Lazy Susan

HNF-3525 Rev. $\not 11$

April 15, 1999

ORIGINAL

Verification $22^{\text {curls }}$ Bearing with separators.

Evaluation 2

Date of test: 4/15/94 Technician: Don Powell OSBaued

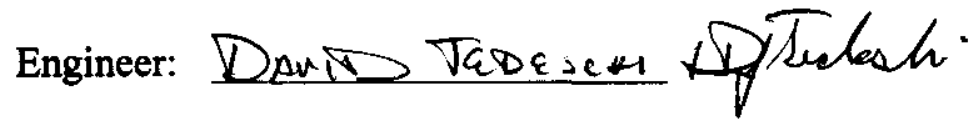

Total Estimated weight applied: lbs

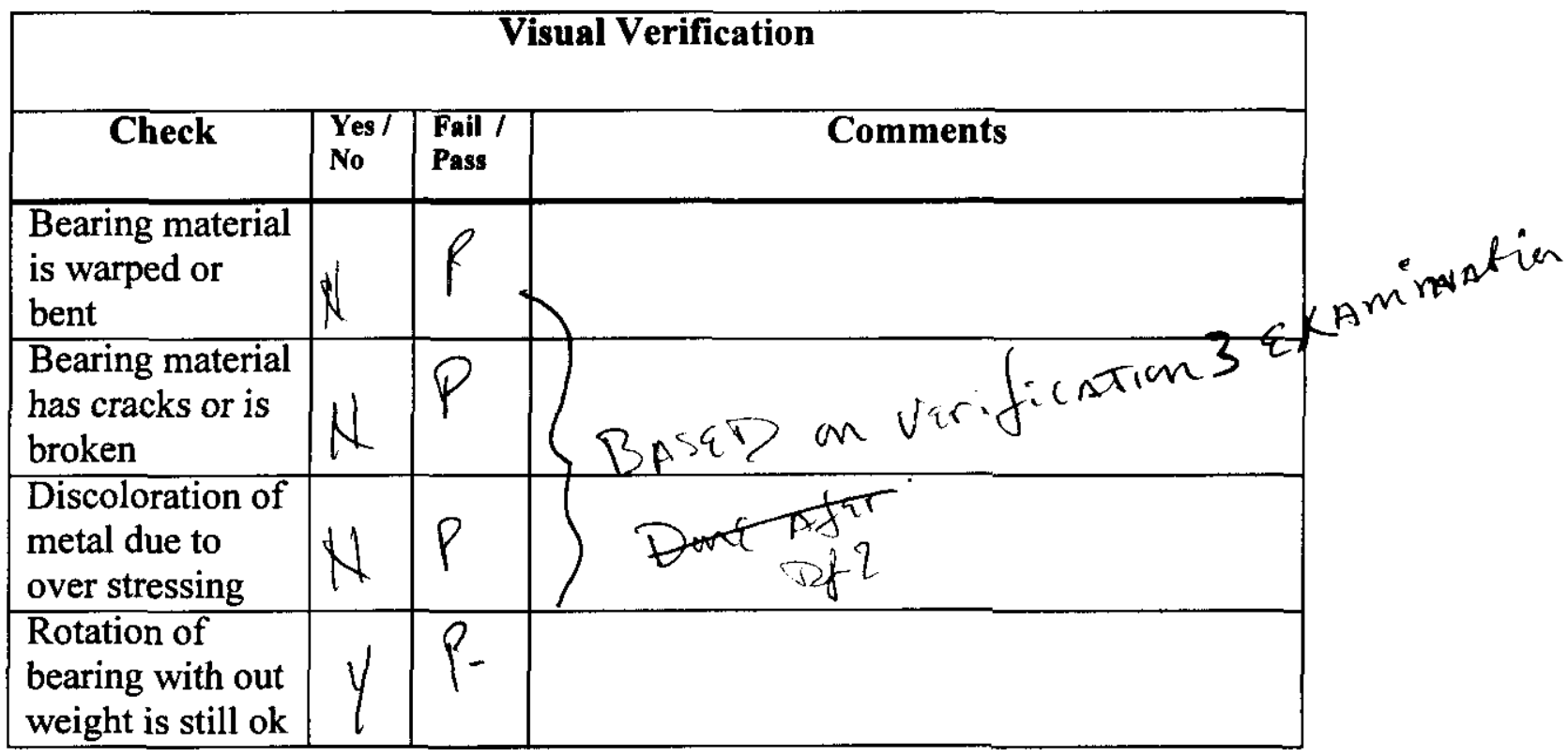

Test Deviations:

upon lowing the Basket it fill (with fully load ad)

Appoxmarely $Z^{\prime \prime}$. It was fill that this was

more of a test than Dropping Another weight on it.

Bearing continued to function. if re e were iv o signs of putyiscal damage.

$C-10$ 
FRS Test Specification for the Lazy Susan

HNF-3525 Rev. $\not \subset l$

April 15, 1999

Verification 3

Evaluation 3 ZCMD Bearing with separator OR/GINAL

Date of test: $1 / 15 / 49$ Technician: Don Powell D2Pawel

Engineer: Davit TEDrxhl

Total Estimated weight applied when $1 / 4$ loaded: $839 \quad$ lbs Total Estimated weight applied when fully loaded: $\frac{843}{254}$ lbs

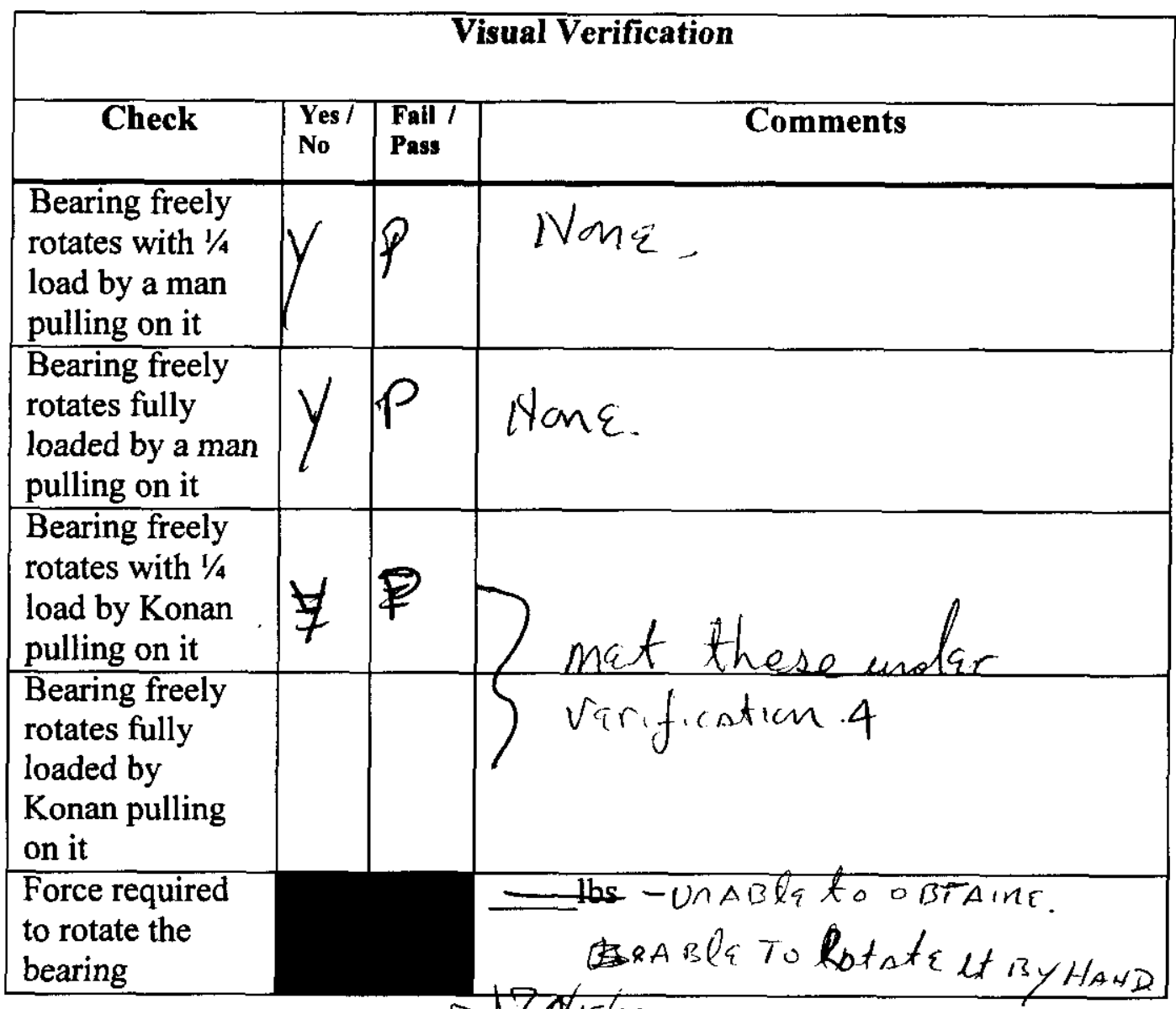

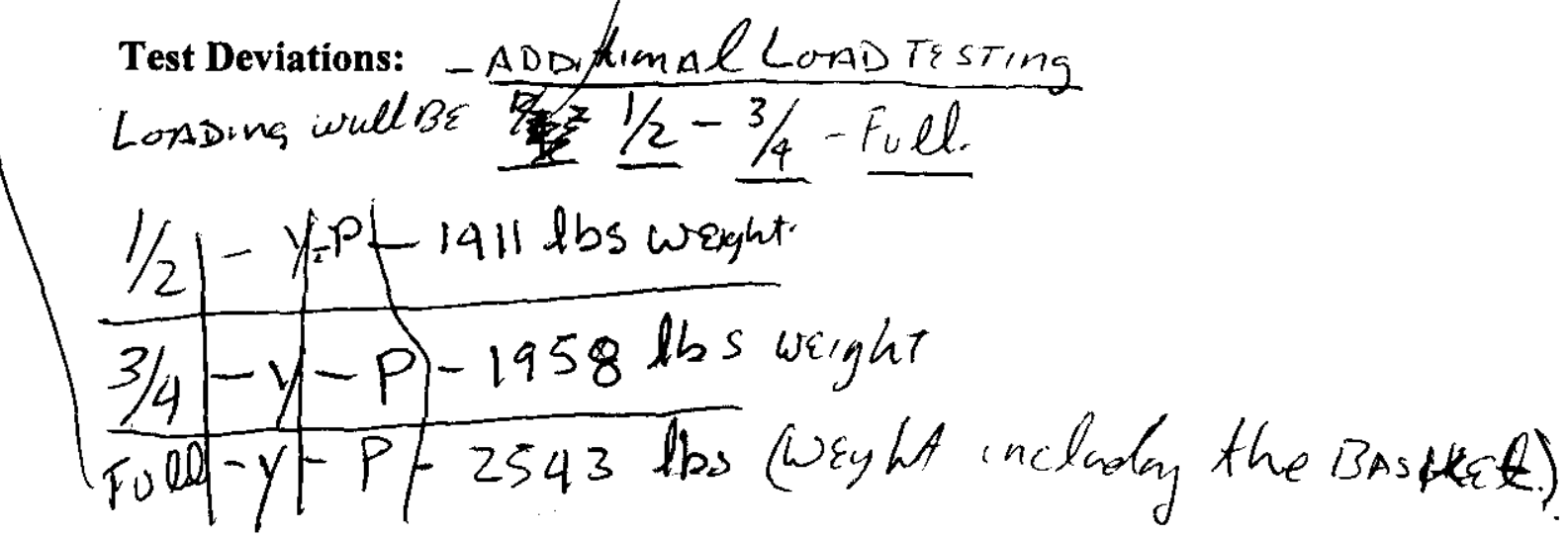

$$
\begin{aligned}
& C-11
\end{aligned}
$$


FRS Test Specification for the Lazy Susan

HNF-3525 Rev. $\varnothing 1$

April 15, 1999

Verification 4 Z ND Basting with separators. OR/GINAL

Evaluation 4

Date of test: $4 / 26 / 9 \%-\quad$ Technician:

$$
5 / 25 / 99
$$

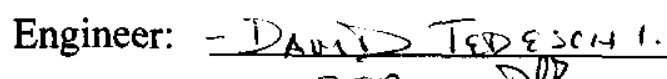

Total Estimated weight applied when 1/4 loaded: 1500

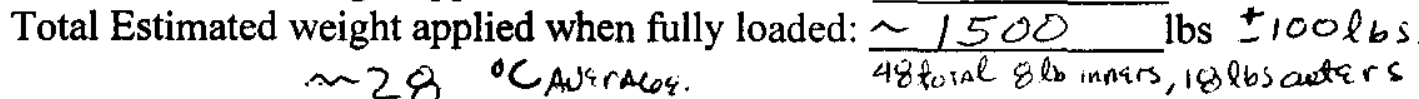

Water Temperature:

F Conductivity of Water:

$\checkmark$

9.1 PH averages.

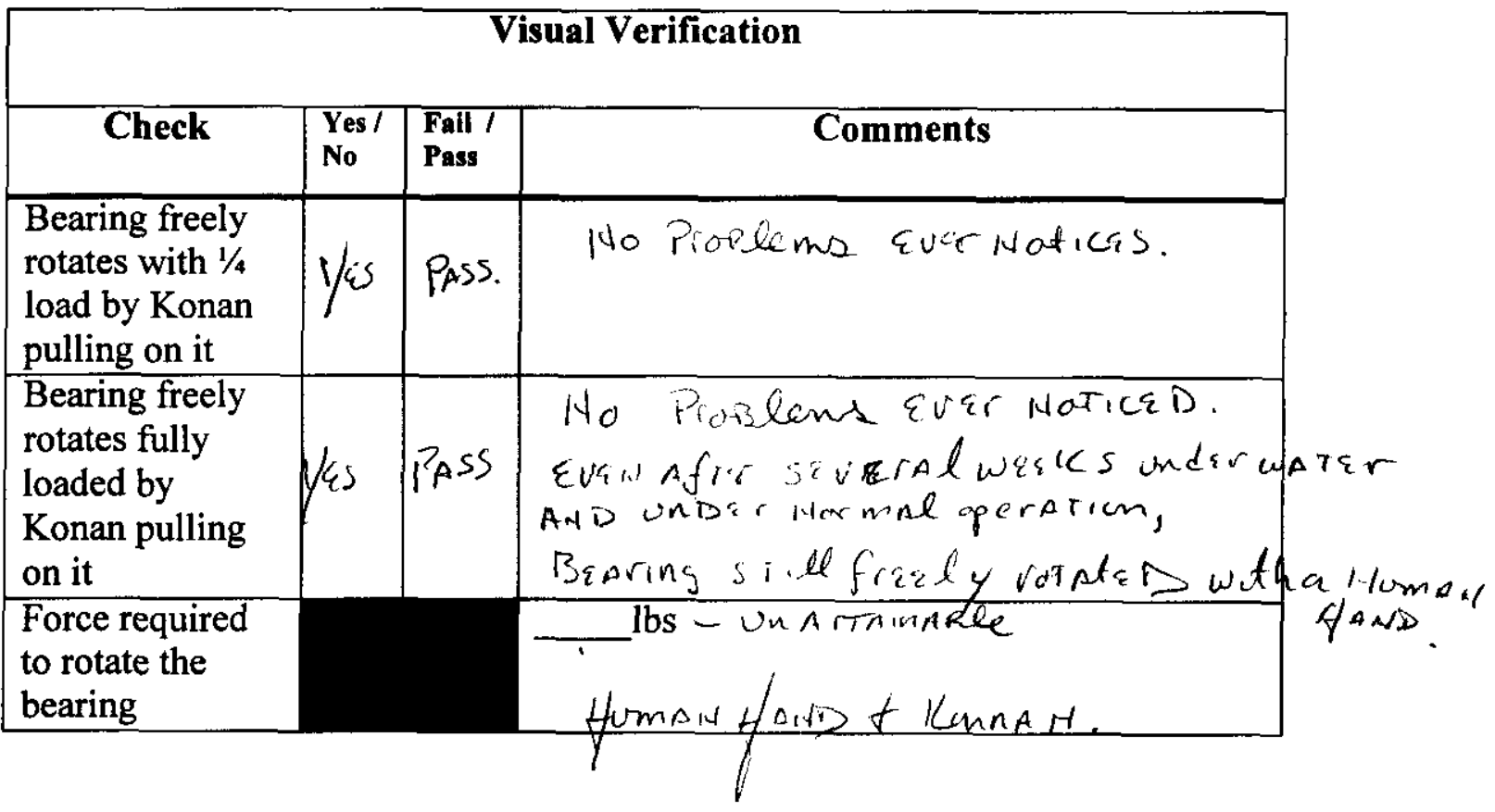

Test Deviations:

TEST Was ron with a validation TESt of tits

Koran operation. Rest was orisirved But Dug

To corrosion of frame. Bearing suffered to visible or physical Problems During is susspasion in water.

Bearing was in water for under 200 Hours But for more than 150 Hows.

$C-12$ 


\section{Verification 5}

No data sheet required. This will be recorded in PNNL Test log if failure occurs.

\subsection{SKETCHES, ADDDITIONAL NOTES...}

Sketch of Test set up for Evaluation 3 and 4.

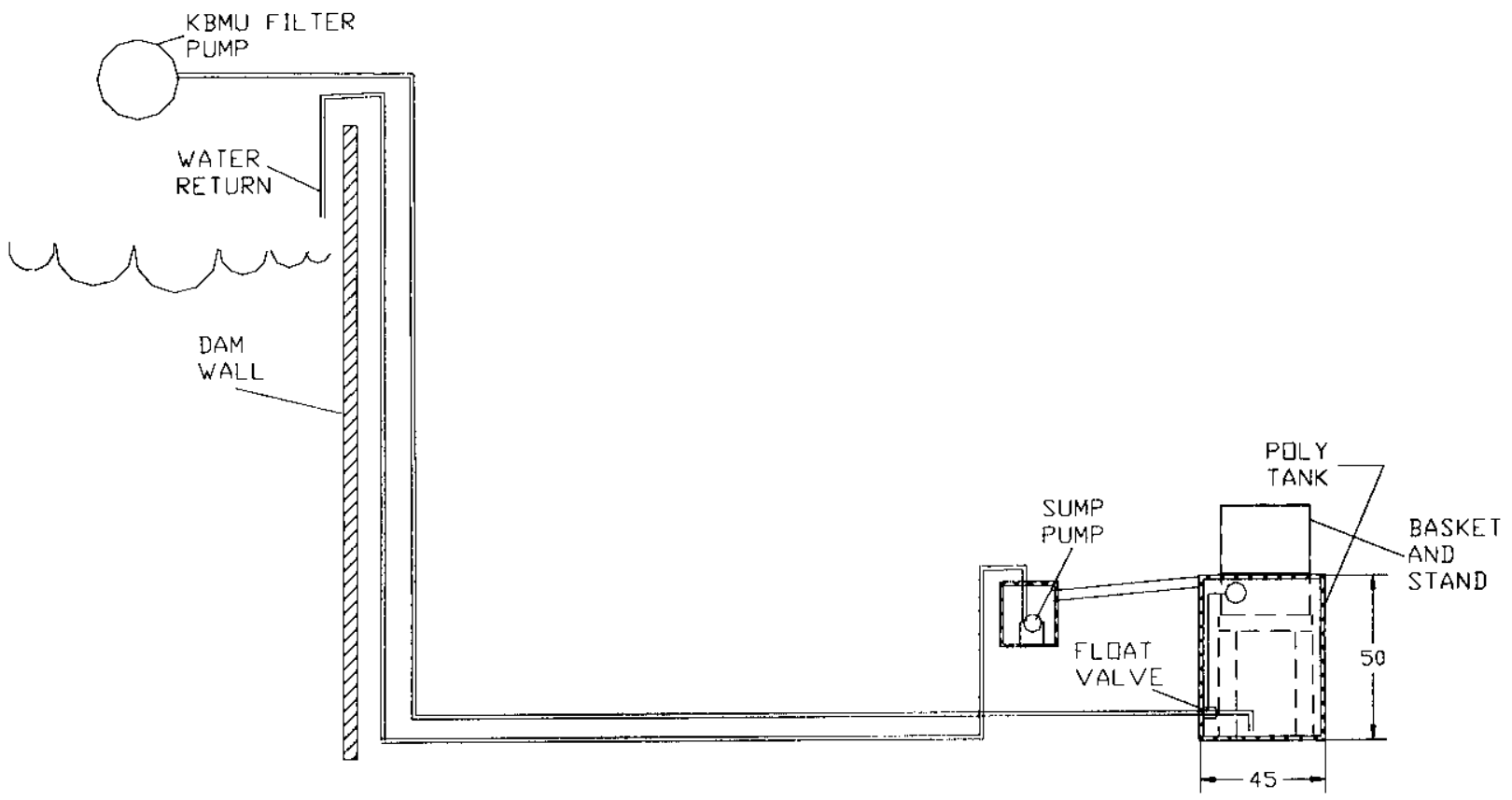

$$
c-13
$$


Fuel Retrieval System Small Tools Design Package

Lazy Susan

HNF-3525 Rev. 1

September 9, 1999

Prem

Appendix D

Test Report

$D-i i$ 


\subsection{Purpose}

The purpose of this test report is to document test results of four verifications performed on the lazy susan. This document will be attached as an Appendix to the lazy susan design package HNF-3525.

\subsection{Verification 1}

\subsection{Setup}

The setup did not differ from the test specification. All testing was performed at the 305 test lab facility in the 300 area. The basket was attached to dynamometer and the dynamometer was attached to a crane. The lazy susan was assembled (without base plates for the frame) and placed on a $1 / 2$ " steel plate. The basket was placed on the lazy susan and centered accordingly. Dummy fuel elements were loaded in to it along with lead bricks to achieve the $3400 \mathrm{lbs}$. The basket was then lifted up with the crane to confirm its weight.

\subsection{Testing and Data}

There were no physical damages incurred to the bearing and it was able to freely rotate after removing the basket.

\subsection{Problems}

The first bearing (containing a full compliment) tested, left excessive silver flakes (dry lubricant) on the metal plate. The second bearing (with retainers) had very slight signs of flaking. Upon closer examination, it is very likely these flakes could have been from previous testing. The second bearing never showed signs of flaking through any of the rest of the tests. Even with the rotational tests, there were no signs of flaking and that's where it was expected to see them.

\subsection{Verification 2}

\subsection{Setup}

The setup used was the same as the previous test. The first bearing tested (containing a full compliment) had a basket loaded to around $3000 \mathrm{lbs}$. resting on it. Next, approximately a $50 \mathrm{lb}$. load was dropped on it. The second bearing test differed from the test specification. Instead of dropping another $50 \mathrm{lb}$. load on it to simulate actual conditions, a worse caseload was applied. After examinations from the first test, the bearing was reassembled and placed under the fully loaded hanging basket. The basket was then lowered on top of the lazy susan but at about 2", the basket free fell.

\subsection{Test Data}

The first bearing was reexamined right away and there were no physical damages incurred. 
The second bearing was not examined right away because verification 3 was performed first. However, after verification 3 , the examination showed the bearing to have suffered no physical damage.

\subsection{Problems}

None

\subsection{Verification 3}

\subsection{Setup}

The test setup was the same, as the previous test except the dynamometer was removed to do the turning. The testing went further than was listed for the second bearing when testing the ease of rotation with the basket $1 / 4,1 / 2,3 / 4$, and fully loaded. The basket was weighed each time the load changed.

\subsection{Test Data}

The first bearing (containing a full compliment) failed to freely rotate with the basket $1 / 4$ loaded and consequently the testing stopped for this bearing. The first bearing would bind and after a few revolutions. It could be unbound by spinning it the opposite direction, but it would then bind in that direction as well. The second bearing tested performed flawlessly. For all load cases, the second bearing was able to freely rotate by a man pulling it.

\subsection{Problems}

Upon examination of the first bearing, it appeared the compliment of balls would collect in one area after rotating and begin to resist each other. This was confirmed through a microscopic evaluation of the balls of which perfect scratches were observed. These scratches could have only developed by the balls rubbing under stress. This observation was confirmed through discussions with Champion bearing. There were no apparent damages to the bearing races. It was then suggested by Champion to buy another bearing with separators for the balls. A second bearing with separators was bought and it had no problems with its testing.

\subsection{Verification 4}

\subsection{Setup}

The setup as depicted in the test specification is what was used. The tank was located under the test table where the loading occurs. The bearing was not in the water for 200 hours but was in it for more than 150 hours. While the bearing was under water, a productivity test for the Konan utilized it. The testing required the bearing to rotate several times, similar to how it would actually be used. The test included 2 baskets loaded per day for five days. 


\subsection{Test Data}

The bearing operated without any problems. After removing it from the water, an examination showed that the plastic kept the outer race from corroding. The table and the bearing holders under went uniform corrosion and (rust) iron oxide formed over all surfaces exposed to the water. There were no signs of physical damage to the bearing and it still rotated with ease even after it dried out.

\subsection{Problems}

None

\subsection{Conclusion}

The bearing with separators worked flawlessly and met the requirements for the design. It is expected that the radiation should not affect it and that it should be able to meet usage expectations. Based on the limited operational information, it is expected that the bearing will not corrode. The final bearing holders and other components that make up the lazy susan will be made of stainless steel thus ensuring no corrosion will take place. The second bearing/lazy susan will continue to be used for testing of the Konan arms for $105 \mathrm{KW}$ except it will not be in water. 